\title{
Synthesis of Azacridone A
}

\author{
Alex Scopton and T. Ross Kelly \\ E. F. Merkert Chemistry Center, Boston College, Chestnut Hill, Massachusetts 02467
}

\section{Supporting Information}

\author{
ross.kelly@bc.edu
}

\section{Table of Contents:}

I. Experimental procedures for the synthesis of $\mathbf{1}, \mathbf{5}, \mathbf{8}, \mathbf{1 2}, \mathbf{1 3}$, 15, 16, 18, 23, 24, 27, 28, 29.

II. $\mathrm{D}_{2} \mathrm{O}$ quench studies and NOESY data of $\mathbf{5}$ and $\mathbf{2 4}$.

III. ${ }^{1} \mathrm{H}$ NMR spectra of $5,8,15,18,24$, isomer of 27, 28, 1 and ${ }^{13} \mathrm{C}$ NMR of 1. 
General Procedures. All reactions were carried out under an atmosphere of argon in flame-dried glassware. The reaction solvents THF, $\mathrm{Et}_{2} \mathrm{O}$ and $\mathrm{CH}_{2} \mathrm{Cl}_{2}$ were purified by passage through activated alumina columns. ${ }^{1} \quad$ Anhydrous $N, N$-dimethylformamide (DMF) was purchased from ACROS and stored over activated $4 \AA$ molecular sieves. $N, N, N$, $N$ '-tetramethylethylenediamine (TMEDA), hexamethylphosphoric triamide (HMPA) and diisopropylethylamine (DIPEA) were distilled from $\mathrm{CaH}_{2}$ and stored over activated $4 \AA$ molecular sieves. $o$-Iodoxybenzoic acid (IBX) was prepared according to the procedure of Dess and Martin. ${ }^{2}$ Alkyllithiums and sodium bis(trimethylsilyl)amide (NaHMDS) were titrated prior to use. ${ }^{3}$ All other reagents were used as received from the manufacturer unless otherwise stated. Preparative TLC was performed on EM Science Silica gel 60500 -micron $(20 \times 20 \mathrm{~cm})$ plates; compounds were extracted off the silica by stirring with 1:1 $\mathrm{MeOH} / \mathrm{CH}_{2} \mathrm{Cl}_{2}$. Flash chromatography was carried out using Bodman reagent silica gel $60 \mathrm{~A}$ (32 - 63 micron). Medium pressure liquid chromatography (MPLC) was carried out using a Biotage Horizon HPFC ${ }^{\text {TM }}$ system with pre-packed KPsilica gel 60A (32 - 63 micron) cartridges. Reactions were monitored by thin layer chromatography using Whatman 250 micron silica gel plates with aluminum backing. All TLC plates were visualized by UV fluorescence quenching. Melting points were recorded on a Fisher-Johns melting point apparatus and are uncorrected. ${ }^{1} \mathrm{H}$ NMR spectra were recorded on a Varian Gemini-400 (400 MHz) spectrometer and are reported in ppm using TMS $(0.00 \mathrm{ppm})$ or solvent (acetone- $\left.\mathrm{d}_{6}=2.05 \mathrm{ppm}\right)$ as an internal standard. Data are reported as: [ $\delta$ shift $]([\mathrm{s}=$ singlet, $\mathrm{d}=$ doublet, $\mathrm{dd}=$ doublet of doublets, $\mathrm{br}=$ broad], $[J=$ coupling constant in $\mathrm{Hz}]$ and [integration]). Proton decoupled ${ }^{13} \mathrm{C} \mathrm{NMR}$ spectra were recorded on a Varian Gemini-400 (100 MHz) spectrometer and are reported in ppm using solvent $\left(\mathrm{CDCl}_{3}=77.0 \mathrm{ppm}\right.$ or acetone- $\left.\mathrm{d}_{6}=29.8 \mathrm{ppm}\right)$ as an internal standard. Low and high resolution mass spectra were obtained at the Boston College mass spectrometry laboratory. Elemental analyses were performed by Atlantic Microlab, Inc. (Norcross, GA).

2,3-Dihydro-5-hydroxy-7-methoxy-2,2-dimethyl-4H-1-benzopyran-4-one (8). ${ }^{4}$ To a<smiles>COc1cc(O)c2c(c1)OC(C)(C)CC2=O</smiles>
stirred suspension of anhydrous phloroglucinol (6, $15.1 \mathrm{~g}, 120$ mmol), 3,3-dimethylacrylic acid (12.1 g, $121 \mathrm{mmol})$ and phosphorous oxychloride (96.5 $\mathrm{mL}, 1050 \mathrm{mmol})$, was added unfused $\mathrm{ZnCl}_{2}(22.9 \mathrm{~g}, 168 \mathrm{mmol})$. The mixture was heated at 50 ${ }^{\circ} \mathrm{C}$ for $3.5 \mathrm{~h}$. The resulting deep-red, homogeneous solution was then poured onto $600 \mathrm{~g}$ of crushed ice and allowed to sit for $12 \mathrm{~h}$. The precipitate was collected by vacuum filtration, washed with $\mathrm{H}_{2} \mathrm{O}(2 \times 100 \mathrm{~mL})$ and dried in air. The solid was dissolved in EtOAc ( $200 \mathrm{~mL})$, adsorbed on ca. $10 \mathrm{~g}$ of silica and passed through a plug of silica $(10 \times 5 \mathrm{~cm})$ with $70: 30$ hexanes/EtOAc to give $12.8 \mathrm{~g}(\sim 61.5 \mathrm{mmol})$ of crude 7 as a pale yellow solid. The solid was added to a flame-dried $250 \mathrm{~mL}$ roundbottomed flask fitted with a reflux condenser and dissolved in dry DMF (100 mL). Then, anhydrous (roasted with a Meeker burner under vacuum) $\mathrm{K}_{2} \mathrm{CO}_{3}(9.81 \mathrm{~g}, 71.0 \mathrm{mmol}$ ) and

\footnotetext{
${ }^{1}$ Pangborn, A. B.; Giardello, M. A.; Grubbs, R. H.; Rosen, R. K.; Timmers, F. J. Organometallics 1996, 15,1518 .

${ }^{2}$ Dess, D. B.; Martin, J. C. J. Amer. Chem. Soc. 1991, 113, 7277.

${ }^{3}$ Duhamel, L.; Plaquevent, J. J. Organomet. Chem. 1993, 448, 1.

${ }^{4}$ Timar, T. J. Heterocycl. Chem. 1988, 25, 871.
} 
MeI $(4.80 \mathrm{~mL}, 77.1 \mathrm{mmol})$ were added to the flask. The reaction mixture was stirred under argon in an $80^{\circ} \mathrm{C}$ oil bath for $20 \mathrm{~h}$, then poured into $\mathrm{H}_{2} \mathrm{O}(300 \mathrm{~mL})$ and extracted with EtOAc $(3 \times 250 \mathrm{~mL})$. The organic extracts were pooled, washed with $\mathrm{H}_{2} \mathrm{O}(3 \times 100$ $\mathrm{mL}$ ) and saturated $\mathrm{NaCl}$ solution $\left(1 \times 200 \mathrm{~mL}\right.$ ), dried with $\mathrm{MgSO}_{4}$ and filtered. Removal of solvents in vacuo gave $15.3 \mathrm{~g}$ of yellow oil. Purification by flash column chromatography $(8 \times 10 \mathrm{~cm}$ silica $)$ with $95: 5$ hexanes/EtOAc yielded $6.47 \mathrm{~g}(24 \%$ over two steps) of a white crystalline solid: $\mathrm{mp} 67-68{ }^{\circ} \mathrm{C}$ (lit. $\left.{ }^{4} \mathrm{mp} 69-70{ }^{\circ} \mathrm{C}\right) ;{ }^{1} \mathrm{H}$ NMR (400 $\left.\mathrm{MHz}, \mathrm{CDCl}_{3}\right) \delta 12.01(\mathrm{~s}, 1 \mathrm{H}), 6.00(\mathrm{~d}, J=2.6 \mathrm{~Hz}, 1 \mathrm{H}), 5.94(\mathrm{~d}, J=2.6 \mathrm{~Hz}, 1 \mathrm{H}), 3.80(\mathrm{~s}$, $3 \mathrm{H}), 2.68(\mathrm{~s}, 2 \mathrm{H}), 1.45(\mathrm{~s}, 6 \mathrm{H}) ;{ }^{13} \mathrm{C}$ NMR $\left(100 \mathrm{MHz}, \mathrm{CDCl}_{3}\right) \delta$ 195.6, 167.7, 163.6, 161.1, 102.7, 94.3, 78.9, 76.7 (overlaps with $\mathrm{CDCl}_{3}$ triplet), 55.6, 47.7, 26.8; $\mathrm{m} / \mathrm{z}$ (ESIMS) $223.09\left(\mathrm{MH}^{+}\right)$.

7-Methoxy-5-(methoxymethoxy)-2,2-dimethyl-2H-chromene (5). A $100 \mathrm{~mL}$ round-<smiles>COc1cc(OC)c2c(c1)OC(C)(C)C=C2</smilesbottomed flask was flame-dried under vacuum and purged with argon. To the flask was added phenol $8(4.01 \mathrm{~g}, 18.0 \mathrm{mmol})$ and $\mathrm{CH}_{2} \mathrm{Cl}_{2}(40 \mathrm{~mL})$. The clear, colorless solution was cooled to $0{ }^{\circ} \mathrm{C}$ (ice/water bath) and chloromethyl methyl ether $(7.20 \mathrm{~mL}, 94.8$ mmol; CAUTION: carcinogen) was added via syringe in one portion (the solution became bright orange). DIPEA (14.5 mL, $83.2 \mathrm{mmol}$ ) was added dropwise over $15 \mathrm{~min}$. The resulting light pink solution was stirred at $0{ }^{\circ} \mathrm{C}$ for $1 \mathrm{~h}$, then allowed to warm to room-temperature and stir under argon. After $20 \mathrm{~h}$, the reaction mixture was poured into saturated $\mathrm{NaHCO}_{3}$ solution $(200 \mathrm{~mL})$ and extracted with EtOAc $(3 \times 100 \mathrm{~mL})$. The organic extracts were pooled, washed with $\mathrm{H}_{2} \mathrm{O}(1 \times 100 \mathrm{~mL})$ and saturated $\mathrm{NaCl}$ solution $(1 \times 100 \mathrm{~mL})$, dried with $\mathrm{MgSO}_{4}$ and filtered. Removal of solvents in vacuo gave $5.09 \mathrm{~g}$ of pale yellow oil. The crude oil was dissolved in roomtemperature $\mathrm{MeOH}(90 \mathrm{~mL})$ and $\mathrm{NaBH}_{4}(2.74 \mathrm{~g}, 72.3 \mathrm{mmol})$ was added in portions over 30 min with stirring. After $2 \mathrm{~h}$, the reaction mixture was poured into $\mathrm{H}_{2} \mathrm{O}(200 \mathrm{~mL})$ and extracted with EtOAc $(3 \times 100 \mathrm{~mL})$. The organics were pooled, washed with $1 \mathrm{~N} \mathrm{HCl}(1$ x $100 \mathrm{~mL}), \mathrm{H}_{2} \mathrm{O}(1 \times 100 \mathrm{~mL})$ and saturated $\mathrm{NaCl}$ solution $(1 \times 100 \mathrm{~mL})$, dried with $\mathrm{MgSO}_{4}$ and filtered. Removal of solvents in vacuo gave $4.72 \mathrm{~g}$ of a pale orange oil, which was dissolved in THF $(60 \mathrm{~mL})$ and $20 \mathrm{~mL}$ of $1 \mathrm{~N} \mathrm{HCl}$ was added. After $2.5 \mathrm{~h}$ of stirring at room temperature, the reaction was poured into saturated $\mathrm{NaHCO}_{3}$ solution $(200 \mathrm{~mL})$ and the resulting mixture was extracted with EtOAc $(3 \times 100 \mathrm{~mL})$. The organic extracts were pooled, washed with $\mathrm{H}_{2} \mathrm{O}(1 \times 100 \mathrm{~mL})$ and saturated $\mathrm{NaCl}$ solution $(1 \mathrm{x}$ $200 \mathrm{~mL}$ ), dried with $\mathrm{MgSO}_{4}$ and filtered. Removal of solvents in vacuo gave $4.48 \mathrm{~g}$ of a light brown oil. Purification by MPLC (100 g silica; $40 \mathrm{~mL} / \mathrm{min}$.; $27 \mathrm{~mL}$ fractions; linear gradient, hexanes $\rightarrow$ 90:10 hexanes/EtOAc over $1296 \mathrm{~mL}$, then isocratic, 90:10 hexanes/EtOAc over $972 \mathrm{~mL})$ yielded $2.72 \mathrm{~g}(60 \%$ over three steps $)$ of the desired product as a clear colorless oil: ${ }^{1} \mathrm{H}$ NMR $\left(400 \mathrm{MHz}, \mathrm{CDCl}_{3}\right) \delta 6.60(\mathrm{~d}, J=9.9 \mathrm{~Hz}, 1 \mathrm{H})$, $6.23(\mathrm{~d}, J=2.2 \mathrm{~Hz}, 1 \mathrm{H}), 6.08(\mathrm{~d}, J=2.2 \mathrm{~Hz}, 1 \mathrm{H}), 5.44(\mathrm{~d}, J=9.9 \mathrm{~Hz}, 1 \mathrm{H}), 5.15(\mathrm{~s}, 2 \mathrm{H})$, $3.74(\mathrm{~s}, 3 \mathrm{H}), 3.47(\mathrm{~s}, 3 \mathrm{H}), 1.41(\mathrm{~s}, 6 \mathrm{H}) ;{ }^{13} \mathrm{C}$ NMR $\left(100 \mathrm{MHz}, \mathrm{CDCl}_{3}\right) \delta$ 160.6, 154.4, 153.5, 126.1, 116.6, 104.9, 95.4, 94.6, 94.2, 76.1, 56.1, 55.3, 27.9; IR (neat) $\vee 2973$, $1623,1575 \mathrm{~cm}^{-1}$; HRMS (ESI) calcd for $\mathrm{C}_{14} \mathrm{H}_{18} \mathrm{O}_{4} \mathrm{Na}\left(\mathrm{MNa}^{+}\right)$273.1103, found 273.1107. 
7-Methoxy-5-(methoxymethoxy)-2,2-dimethyl-2H-1-benzopyran-6-carboxaldehyde<smiles>COc1cc2c(c(OC)c1C=O)C=CC(C)(C)O2</smiles>
(12). A $25 \mathrm{~mL}$ round-bottomed flask, containing chromene 5 (275 $\mathrm{mg}, 1.10 \mathrm{mmol})$, was flame-dried mildly under vacuum and purged with argon. $\mathrm{Et}_{2} \mathrm{O}(9.0 \mathrm{~mL})$ was added and the clear colorless solution was cooled to $0{ }^{\circ} \mathrm{C}$. ${ }^{n} \mathrm{BuLi}(0.530 \mathrm{~mL}, 2.50 \mathrm{M}$ solution in hexane, $1.33 \mathrm{mmol}$ ) was added dropwise over $2 \mathrm{~min}$ and the reaction was allowed to stir under argon at $0{ }^{\circ} \mathrm{C}$ (ice/water bath) for $1.5 \mathrm{~h}$. DMF $(0.150$ $\mathrm{mL}, 1.94 \mathrm{mmol}$ ) was added in one portion via syringe and the reaction was allowed to warm to room temperature. After stirring for $18 \mathrm{~h}$, saturated $\mathrm{NH}_{4} \mathrm{Cl}$ solution (ca. $5 \mathrm{~mL}$ ) was added, followed by dilution with $\mathrm{H}_{2} \mathrm{O}(\mathrm{ca} .10 \mathrm{~mL})$ and extraction with EtOAc $(3 \times 30$ $\mathrm{mL})$. The organic extracts were pooled, washed with $\mathrm{H}_{2} \mathrm{O}(1 \times 30 \mathrm{~mL})$ and saturated $\mathrm{NaCl}$ solution $\left(1 \times 30 \mathrm{~mL}\right.$ ), dried with $\mathrm{MgSO}_{4}$ and filtered. Removal of solvents in vacuo gave $342 \mathrm{mg}$ of pale yellow oil, which was purified by flash column chromatography $(2 \mathrm{x}$ $10 \mathrm{~cm}$ silica) with 88:12 hexanes/EtOAc to yield $223 \mathrm{mg}(73 \%)$ of the desired product as a clear colorless oil, which solidified overnight $(12 \mathrm{~h})$ to afford an off-white solid: $\mathrm{mp}$ 55-56 ${ }^{\circ} \mathrm{C} ;{ }^{1} \mathrm{H}$ NMR $\left(400 \mathrm{MHz}, \mathrm{CDCl}_{3}\right) \delta 10.28(\mathrm{~s}, 1 \mathrm{H}), 6.62(\mathrm{~d}, J=10.3 \mathrm{~Hz}, 1 \mathrm{H}), 6.23$ $(\mathrm{s}, 1 \mathrm{H}), 5.57(\mathrm{~d}, J=10.3 \mathrm{~Hz}, 1 \mathrm{H}), 5.08(\mathrm{~s}, 2 \mathrm{H}), 3.86(\mathrm{~s}, 3 \mathrm{H}), 3.56(\mathrm{~s}, 3 \mathrm{H}), 1.45(\mathrm{~s}, 6 \mathrm{H})$; ${ }^{13} \mathrm{C}$ NMR $\left(100 \mathrm{MHz}, \mathrm{CDCl}_{3}\right) \delta 187.1,163.5,159.9,155.9,127.6,116.3,111.9,108.3$, 101.6, 96.0, 77.8, 57.8, 56.0, 28.3; IR (neat) v 2980, 2790, 1677, 1634, 1599, $1568 \mathrm{~cm}^{-1}$; $m / z$ (ESI-MS) $301.06\left(\mathrm{MNa}^{+}\right)$; Anal. Calcd for $\mathrm{C}_{15} \mathrm{H}_{18} \mathrm{O}_{5}: \mathrm{C}, 64.74 ; \mathrm{H}, 6.52$. Found: $\mathrm{C}$, $64.81 ; \mathrm{H}, 6.56$.

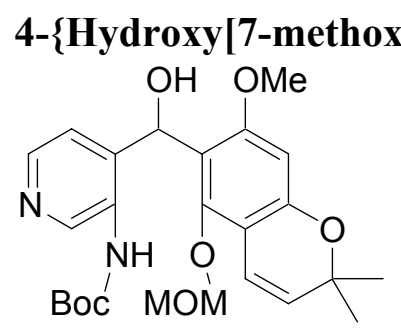

-5-(methoxymethoxy)-2,2-dimethyl-2H-benzopyran-6yl]methyl\}-3-pyridinylcarbamic acid, 1,1-dimethylethyl ester (15). To a flame-dried, $15 \mathrm{~mL}$ round-bottomed flask, purged with argon, was added pyridine $13(130 \mathrm{mg}, 0.668 \mathrm{mmol})$ and THF $(3.0 \mathrm{~mL})$. The orange solution was cooled to $-78{ }^{\circ} \mathrm{C}$ $\left(\mathrm{CO}_{2}\right.$ /acetone bath) and ${ }^{t} \mathrm{BuLi}(0.865 \mathrm{~mL}, 1.65 \mathrm{M}$ solution in pentane, $1.43 \mathrm{mmol}$ ) was added dropwise over $5 \mathrm{~min}$. The resulting deep red solution was stirred at $-78^{\circ} \mathrm{C}$ for $2 \mathrm{~h}$, then aldehyde 12 (181 $\mathrm{mg}, 0.649$ mmol) was added via cannula over $1 \mathrm{~min}$ as a solution in THF $(3 \mathrm{~mL})$. The reaction was allowed to warm to room temperature overnight as the cold bath evaporated. After $14 \mathrm{~h}$, saturated $\mathrm{NH}_{4} \mathrm{Cl}$ solution (ca. $5 \mathrm{~mL}$ ) was added, the mixture was diluted with $\mathrm{H}_{2} \mathrm{O}$ (ca. 20 $\mathrm{mL})$ and then extracted with EtOAc $(3 \times 20 \mathrm{~mL})$. The organic extracts were pooled, washed with $\mathrm{H}_{2} \mathrm{O}(1 \times 20 \mathrm{~mL})$ and saturated $\mathrm{NaCl}$ solution $(1 \times 20 \mathrm{~mL})$, dried with $\mathrm{MgSO}_{4}$ and filtered. Removal of solvents in vacuo gave $314 \mathrm{mg}$ of a yellow foam. Purification by flash column chromatography $(3 \times 6 \mathrm{~cm}$ silica) with 1:1 hexanes/EtOAc yielded $180 \mathrm{mg}(59 \%)$ of a white foam: $\mathrm{mp} 77-80{ }^{\circ} \mathrm{C}$ (a small amount was ground to a fine powder with a mortar and pestle); ${ }^{1} \mathrm{H} \mathrm{NMR}\left(400 \mathrm{MHz}, \mathrm{CDCl}_{3}\right) \delta 9.19$ (br s, $\left.1 \mathrm{H}\right)$, 8.19 (br s, 1H), 8.14 (d, $J=5.1 \mathrm{~Hz}, 1 \mathrm{H}), 6.86$ (d, $J=5.1 \mathrm{~Hz}, 1 \mathrm{H}), 6.43$ (d, $J=9.9 \mathrm{~Hz}$, $1 \mathrm{H}), 6.32(\mathrm{~s}, 1 \mathrm{H}), 6.17(\mathrm{~d}, J=10.3 \mathrm{~Hz}, 1 \mathrm{H}), 5.56(\mathrm{~d}, J=9.9 \mathrm{~Hz}, 1 \mathrm{H}), 4.90(\mathrm{~s}, 2 \mathrm{H}), 4.52$ $(\mathrm{d}, J=10.3 \mathrm{~Hz}, 1 \mathrm{H}), 3.73$ (s, 3H), 3.40 (s, 3H), 1.53 (s, 9H), 1.45 (s, 3H), 1.44 (s, 3H); ${ }^{13} \mathrm{C}$ NMR $\left(100 \mathrm{MHz}, \mathrm{CDCl}_{3}\right) \delta 157.9,154.9,152.6,152.3,143.1,142.4,139.1,133.9$, $128.0,120.8,116.8,113.2$, 108.2, 100.5, 97.1, 80.4, 76.5, 66.3, 57.6, 55.8, 28.4, 27.9, 27.8; IR (KBr) v 3342, 2980, 2934, 1727, 1607, 1572, $1521 \mathrm{~cm}^{-1} ; \mathrm{m} / z$ (ESI-MS) 473.17 $\left(\mathrm{MH}^{+}\right), 495.17\left(\mathrm{MNa}^{+}\right)$. 


\section{4-\{[7-Methoxy-5-(methoxymethoxy)-2,2-dimethyl-2H-benzo-pyran-6-yl]carbonyl $\}$-3-}<smiles>COc1cc2c(c(OC)c1C(=O)c1ccncc1NC(=O)OCc1ccccc1)C=CC(C)(C)O2</smiles>

pyridinylcarbamic acid, 1,1-dimethylethyl ester (16). To a stirred solution of alcohol 15 (154 $\mathrm{mg}, 0.326 \mathrm{mmol})$ in DMSO $(3.0 \mathrm{~mL})$ at room temperature was added IBX $(183 \mathrm{mg}, 0.652$ mmol) in one portion, which gave a mixture that became homogeneous in $2-3 \mathrm{~min}$. After $2 \mathrm{~h}$, the bright yellow solution was poured into $\mathrm{H}_{2} \mathrm{O}(10 \mathrm{~mL})$ and the resulting mixture was extracted with EtOAc $(3 \times 20 \mathrm{~mL})$. The organics were pooled, washed with $\mathrm{H}_{2} \mathrm{O}(1 \times 30$ $\mathrm{mL})$ and saturated $\mathrm{NaCl}$ solution $(1 \times 30 \mathrm{~mL})$, dried with $\mathrm{MgSO}_{4}$ and filtered. Removal of solvents in vacuo gave $158 \mathrm{mg}$ of a yellow oil. Passage through a plug of silica $(2 \times 2$ $\mathrm{cm})$ with 80:20 hexanes/EtOAc yielded $152 \mathrm{mg}(99 \%)$ of a yellow foam: mp 55-57 ${ }^{\circ} \mathrm{C}$ (a small amount was ground to a fine powder with a mortar and pestle); ${ }^{1} \mathrm{H}$ NMR (400 $\left.\mathrm{MHz}_{\mathrm{CDCl}}\right) \delta 10.37(\mathrm{~s}, 1 \mathrm{H}), 9.80(\mathrm{~s}, 1 \mathrm{H}), 8.29(\mathrm{~d}, J=5.1 \mathrm{~Hz}, 1 \mathrm{H}), 7.29(\mathrm{~d}, J=5.1 \mathrm{~Hz}$, $1 \mathrm{H}), 6.50(\mathrm{~d}, J=9.9 \mathrm{~Hz}, 1 \mathrm{H}), 6.28(\mathrm{~s}, 1 \mathrm{H}), 5.58(\mathrm{~d}, J=9.9 \mathrm{~Hz}, 1 \mathrm{H}), 4.88(\mathrm{~s}, 2 \mathrm{H}), 3.64(\mathrm{~s}$, $3 \mathrm{H}), 3.24(\mathrm{~s}, 3 \mathrm{H}), 1.56(\mathrm{~s}, 9 \mathrm{H}), 1.47(\mathrm{~s}, 6 \mathrm{H}) ;{ }^{13} \mathrm{C} \mathrm{NMR}\left(100 \mathrm{MHz}, \mathrm{CDCl}_{3}\right) \delta$ 197.6, 157.7, 156.6, 152.3, 151.9, 142.3 (2 peaks overlapped), 135.4, 128.0, 127.2, 124.5, 116.3, 115.1, 108.2, 100.5, 96.4, 81.1, 77.0 (overlaps with middle peak of $\mathrm{CDCl}_{3}$ triplet), 57.2, 55.8, 28.3, 28.0; IR $(\mathrm{KBr}) \vee 3300,2976,2930,1735,1653,1603,1560,1509 \mathrm{~cm}^{-1} ; \mathrm{m} / z(\mathrm{ESI}-$ MS) $471.24\left(\mathrm{MH}^{+}\right), 493.24\left(\mathrm{MNa}^{+}\right)$; Anal. Calcd for $\mathrm{C}_{25} \mathrm{H}_{30} \mathrm{~N}_{2} \mathrm{O}_{7}: \mathrm{C}, 63.82 ; \mathrm{H}, 6.43 ; \mathrm{N}$, 5.95. Found: C, 64.13; H, 6.46; N, 5.84.

\section{2,11-Dihydro-5-hydroxy-2,2,11-trimethyl-6H-benzopyrano[7,6-b][1,7]naphthyridin-}<smiles>Cn1c2ccncc2c(=O)c2c(O)c3c(cc21)OC(C)(C)C=C3</smiles>

6-one (18). To a flame-dried $10 \mathrm{~mL}$ round-bottomed flask, purged with argon, was added ketone 16 (60.6 mg, 0.129 mmol) and DMF (1.0 mL). The solution was cooled to $0{ }^{\circ} \mathrm{C}$ and $\mathrm{NaH}(4.7 \mathrm{mg}, 60 \%$ dispersion in mineral oil, $0.20 \mathrm{mmol})$ was added in one portion. The reaction mixture was stirred at $0{ }^{\circ} \mathrm{C}$ for $10 \mathrm{~min}$, then allowed to warm to room temperature.

After stirring for $1 \mathrm{~h}$, the bright yellow solution was cooled to $0^{\circ} \mathrm{C}$ and $\mathrm{MeI}(8.1 \mu \mathrm{L}, 0.13$ mmol) was added via syringe. The resulting bright red solution was stirred at $0{ }^{\circ} \mathrm{C}$ for 1 $\mathrm{h}$, then allowed to warm to room temperature and stir for an additional $1.5 \mathrm{~h}$. The reaction mixture was poured into $\mathrm{H}_{2} \mathrm{O}(20 \mathrm{~mL})$ and extracted with EtOAc $(3 \times 30 \mathrm{~mL})$. The organic extracts were pooled, washed with $\mathrm{H}_{2} \mathrm{O}(3 \times 10 \mathrm{~mL})$ and saturated $\mathrm{NaCl}$ solution ( $1 \times 30 \mathrm{~mL})$, dried with $\mathrm{MgSO}_{4}$ and filtered. Removal of solvents in vacuo gave $55.7 \mathrm{mg}$ of a yellow/orange wax. The crude wax was dissolved in undried $\mathrm{CH}_{2} \mathrm{Cl}_{2}(1$ $\mathrm{mL}$ ) and trifluoroacetic acid (TFA, $0.5 \mathrm{~mL}$ ) was added. The resulting bright red solution was stirred overnight at room temperature open to air. After $16 \mathrm{~h}$, it was poured into saturated $\mathrm{NaHCO}_{3}$ solution $(20 \mathrm{~mL})$ and extracted with EtOAc $(3 \times 30 \mathrm{~mL})$. The organic extracts were pooled, washed with saturated $\mathrm{NaHCO}_{3}$ solution $(1 \times 20 \mathrm{~mL})$ and saturated $\mathrm{NaCl}$ solution $(1 \times 20 \mathrm{~mL})$, dried with $\mathrm{MgSO}_{4}$ and filtered. Removal of solvents in vacuo gave $46.8 \mathrm{mg}$ of a bright yellow/orange solid. Purification by flash column chromatography $(1.5 \times 10 \mathrm{~cm}$ silica) yielded $14.2 \mathrm{mg}(36 \%)$ of an orange solid: $\mathrm{mp} 253-$ $256{ }^{\circ} \mathrm{C}$ (dec); ${ }^{1} \mathrm{H}$ NMR (400 MHz, $\left.\mathrm{CDCl}_{3}\right) \delta 14.56$ (s, 1H), 9.07 (br s, $\left.1 \mathrm{H}\right), 8.53$ (br d, $J=$ $4.9 \mathrm{~Hz}, 1 \mathrm{H}), 8.18(\mathrm{~d}, J=4.9 \mathrm{~Hz}, 1 \mathrm{H}), 6.76(\mathrm{~d}, J=10.1 \mathrm{~Hz}, 1 \mathrm{H}), 6.32(\mathrm{~s}, 1 \mathrm{H}), 5.62(\mathrm{~d}, J=$ $10.1 \mathrm{~Hz}, 1 \mathrm{H}), 3.88(\mathrm{~s}, 3 \mathrm{H}), 1.50(\mathrm{~s}, 6 \mathrm{H}) ;{ }^{13} \mathrm{C} \mathrm{NMR}\left(100 \mathrm{MHz}, \mathrm{CDCl}_{3}\right) \delta 179.5,160.9$, $159.4,143.9,141.2,138.4,127.2,125.1,117.8,115.4,106.0,103.1,91.6,78.4,33.7$, 
29.8, 28.7; IR $(\mathrm{KBr}) \vee 2965,2922,2852,1630,1544,1462 \mathrm{~cm}^{-1}$; HRMS (ESI) calcd for $\mathrm{C}_{18} \mathrm{H}_{17} \mathrm{~N}_{2} \mathrm{O}_{3}\left(\mathrm{MH}^{+}\right)$309.1239, found 309.1236.

\section{2,3-Dihydro-5-hydroxy-7-(methoxymethoxy)-2,2-dimethyl-4H-1-benzopyran-4-one}

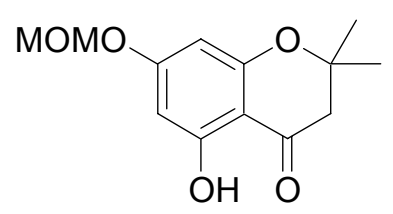

(23). A $100 \mathrm{~mL}$ round-bottomed flask was flame-dried and purged with argon. To the flask was added anhydrous phloroglucinol $(6,5.14 \mathrm{~g}, 40.9 \mathrm{mmol}), 3,3$-dimethylacrylic acid (4.08 g, $40.8 \mathrm{mmol})$, unfused $\mathrm{ZnCl}_{2}(7.80 \mathrm{~g}, 57.2 \mathrm{mmol})$ and phosphorous oxychloride $(33.0 \mathrm{~mL}, 360 \mathrm{mmol})$. The mixture was heated to $50{ }^{\circ} \mathrm{C}$ and stirred at that temperature for $4 \mathrm{~h}$ under argon. The resulting deep-red, homogeneous solution was then poured onto $200 \mathrm{~g}$ crushed ice and allowed to sit for $36 \mathrm{~h}$. The precipitate was collected by vacuum filtration and dried in air. The 8.68 $\mathrm{g}$ of orange/brown solid thus obtained was passed through a $5 \times 2 \mathrm{~cm}$ plug of silica with 70:30 hexanes/EtOAc to give $5.95 \mathrm{~g}(28.6 \mathrm{mmol})$ of crude 7 as an off-white solid. The crude material was then added to a flame-dried $250 \mathrm{~mL}$ round-bottomed flask fitted with a reflux condenser and dissolved in dry DMF $(50 \mathrm{~mL})$. Then were added anhydrous (roasted with a Meeker burner under vacuum) $\mathrm{K}_{2} \mathrm{CO}_{3}$ (4.39 g, $31.8 \mathrm{mmol}$ ) and $\mathrm{MOMCl}$ $(2.40 \mathrm{~mL}, 31.6 \mathrm{mmol})$. The mixture was stirred under argon at room temperature for 12 $\mathrm{h}$, then poured onto $\mathrm{H}_{2} \mathrm{O}(\sim 100 \mathrm{~mL})$ and extracted with EtOAc $(3 \times 100 \mathrm{~mL})$. The organic extracts were pooled, washed with $\mathrm{H}_{2} \mathrm{O}(3 \times 50 \mathrm{~mL})$ and saturated $\mathrm{NaCl}$ solution $\left(1 \times 100 \mathrm{~mL}\right.$ ), dried with $\mathrm{MgSO}_{4}$ and filtered. Removal of solvents in vacuo gave $6.96 \mathrm{~g}$ of a dark red oil. Purification by flash column chromatography $(5 \times 7.5 \mathrm{~cm}$ silica) with 95:5 hexane/EtOAc yielded $3.91 \mathrm{~g}$ (38\% over two steps) of a white crystalline solid: $\mathrm{mp}$ 66-67 ${ }^{\circ} \mathrm{C} ;{ }^{1} \mathrm{H}$ NMR $\left(400 \mathrm{MHz}, \mathrm{CDCl}_{3}\right) \delta 11.93(\mathrm{~s}, 1 \mathrm{H}), 6.13(\mathrm{~d}, J=2.2 \mathrm{~Hz}, 1 \mathrm{H}), 6.06(\mathrm{~d}$, $J=2.2 \mathrm{~Hz}, 1 \mathrm{H}), 5.16(\mathrm{~s}, 2 \mathrm{H}), 3.47(\mathrm{~s}, 3 \mathrm{H}), 2.69(\mathrm{~s}, 2 \mathrm{H}), 1.45(\mathrm{~s}, 6 \mathrm{H}) ;{ }^{13} \mathrm{C}$ NMR $(100$ $\left.\mathrm{MHz}, \mathrm{CDCl}_{3}\right) \delta 195.9,165.3,163.4,161.2,102.9,96.2,95.8,93.8,78.9,56.4,47.8,26.8$; IR $(\mathrm{KBr}) \vee 3427,2984,1649,1583 \mathrm{~cm}^{-1}$; HRMS (ESI) calcd. for $\mathrm{C}_{13} \mathrm{H}_{17} \mathrm{O}_{5}\left(\mathrm{MH}^{+}\right)$ 253.1076, found 253.1065; Anal. Calcd. for $\mathrm{C}_{13} \mathrm{H}_{16} \mathrm{O}_{5}: \mathrm{C}, 61.90 ; \mathrm{H}, 6.39$. Found: $\mathrm{C}$, $61.91 ; \mathrm{H}, 6.34$.

5-Methoxy-7-(methoxymethoxy)-2,2-dimethyl-2H-chromene (24). A $25 \mathrm{~mL}$ round-<smiles>COc1cc(OC)c2c(c1)OC(C)(C)C=C2</smilesbottomed flask attached to a reflux condenser was flame-dried under vacuum and purged with argon. To the flask was added phenol 23 (1.53 g, $6.08 \mathrm{mmol}$ ), anhydrous (roasted with a Meeker burner under vacuum) $\mathrm{K}_{2} \mathrm{CO}_{3}(1.69 \mathrm{~g}, 12.2 \mathrm{mmol})$ and dry DMF (6.0 mL). Methyl iodide $(1.20 \mathrm{~mL}, 19.3 \mathrm{mmol})$ was then added via syringe in one portion and the mixture was stirred at $80{ }^{\circ} \mathrm{C}$ under argon. After $2.5 \mathrm{~h}$, the reaction was allowed to cool to room temperature, poured into $\mathrm{H}_{2} \mathrm{O}(\sim 50$ $\mathrm{mL})$ and extracted with EtOAc $(3 \times 60 \mathrm{~mL})$. The organic extracts were pooled, washed with $\mathrm{H}_{2} \mathrm{O}(3 \times 30 \mathrm{~mL})$ and saturated $\mathrm{NaCl}$ solution $(1 \times 50 \mathrm{~mL})$, dried with $\mathrm{MgSO}_{4}$ and filtered. Removal of solvents in vacuo gave $1.56 \mathrm{~g}$ of a white solid. The crude solid was dissolved in $15 \mathrm{~mL}$ of room-temperature $\mathrm{MeOH}$ and $\mathrm{NaBH}_{4}(693 \mathrm{mg}, 18.3 \mathrm{mmol})$ was added in portions over $20 \mathrm{~min}$ with stirring. After $3 \mathrm{~h}$, the reaction was poured into $\mathrm{H}_{2} \mathrm{O}$ $(\sim 50 \mathrm{~mL})$ and the resulting mixture was extracted with EtOAc $(3 \times 50 \mathrm{~mL})$. The organic extracts were pooled, washed with $1 \mathrm{~N} \mathrm{HCl}(1 \times 30 \mathrm{~mL})$ and saturated $\mathrm{NaCl}$ solution $(1 \mathrm{x}$ $50 \mathrm{~mL}$ ), dried with $\mathrm{MgSO}_{4}$ and filtered. Removal of solvents in vacuo gave $1.65 \mathrm{~g}$ of a 
clear colorless oil. The crude oil was dissolved in $25 \mathrm{~mL}$ of THF and $6 \mathrm{~mL}$ of $1 \mathrm{~N} \mathrm{HCl}$ was added. After $5 \mathrm{~h}$ of stirring at room temperature, the reaction was poured into saturated $\mathrm{NaHCO}_{3}$ solution $(\sim 30 \mathrm{~mL})$ and extracted with EtOAc $(3 \times 50 \mathrm{~mL})$. The organic extracts were pooled, washed with saturated $\mathrm{NaCl}$ solution $(1 \times 50 \mathrm{~mL})$, dried with $\mathrm{MgSO}_{4}$ and filtered. Removal of solvents in vacuo gave $1.48 \mathrm{~g}$ of a clear colorless oil. Purification by flash column chromatography $(3 \mathrm{x} 15 \mathrm{~cm}$ silica) with 97:3 hexanes $/ \mathrm{Et}_{2} \mathrm{O}$ yielded $905 \mathrm{mg}$ ( $60 \%$ over three steps) of $\mathbf{2 4}$ product as a clear colorless oil: ${ }^{1} \mathrm{H}$ NMR $\left(400 \mathrm{MHz}, \mathrm{CDCl}_{3}\right) \delta 6.57(\mathrm{~d}, J=9.9 \mathrm{~Hz}, 1 \mathrm{H}), 6.18(\mathrm{~d}, J=2.2 \mathrm{~Hz}, 1 \mathrm{H}), 6.12$ (d, $J=2.2 \mathrm{~Hz}, 1 \mathrm{H}), 5.43(\mathrm{~d}, J=9.9 \mathrm{~Hz}, 1 \mathrm{H}), 5.12(\mathrm{~s}, 2 \mathrm{H}), 3.78(\mathrm{~s}, 3 \mathrm{H}), 3.47(\mathrm{~s}, 3 \mathrm{H}), 1.40$ (s, 6H); ${ }^{13} \mathrm{C}$ NMR $\left(100 \mathrm{MHz}, \mathrm{CDCl}_{3}\right) \delta 158.3,155.8,154.3,126.3,116.4,105.0,96.9$, 94.4, 92.7, 76.1, 56.1, 55.6, 27.9; IR (neat) $\vee 2968,1633,1579 \mathrm{~cm}^{-1}$; HRMS (ESI) calcd for $\mathrm{C}_{14} \mathrm{H}_{18} \mathrm{O}_{4} \mathrm{Na}\left(\mathrm{MNa}^{+}\right)$273.1103, found 273.1101.

\section{5-Methoxy-7-(methoxymethoxy)-2,2-dimethyl-2H-1-benzopyran-6-carboxaldehyde}

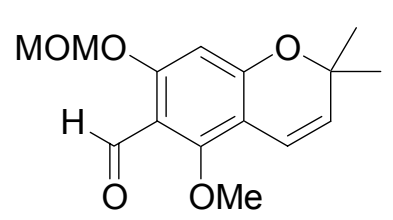

(27). A $10 \mathrm{~mL}$ round-bottomed flask, containing the starting chromene 24 (99.5 mg, $0.398 \mathrm{mmol})$, was mildly flame-dried under vacuum and purged with argon. To the flask was added THF $(2.0 \mathrm{~mL})$ and HMPA $(0.166 \mathrm{~mL}, 0.954 \mathrm{mmol})$. The clear solution was cooled to $0{ }^{\circ} \mathrm{C}$ (ice/water bath) and ${ }^{n} \mathrm{BuLi}(0.200$

$\mathrm{mL}, 2.38 \mathrm{M}$ solution in hexane, $0.476 \mathrm{mmol}$ ) was added dropwise over $5 \mathrm{~min}$. The resulting bright orange solution was stirred at $0{ }^{\circ} \mathrm{C}$ under argon for $1.5 \mathrm{~h}$. Iron pentacarbonyl $(0.073 \mathrm{~mL}, 0.555 \mathrm{mmol}$; CAUTION: pyrophoric and highly toxic) was added dropwise over $1 \mathrm{~min}$. The reaction was allowed to warm to room temperature and stir for $2.5 \mathrm{~h}$. Glacial acetic acid $(0.250 \mathrm{~mL}, 4.37 \mathrm{mmol})$ was added in one portion and the brown reaction mixture was stirred for $15 \mathrm{~min}$. Dilution with EtOAc $(\sim 50 \mathrm{~mL})$ was followed by washing with $1 \mathrm{~N} \mathrm{HCl}(1 \times 20 \mathrm{~mL}), 1 \mathrm{~N} \mathrm{NaOH}(1 \times 20 \mathrm{~mL})$ and saturated $\mathrm{NaCl}$ solution $(1 \times 20 \mathrm{~mL})$. The organic layer was dried with $\mathrm{MgSO}_{4}$ and filtered. Removal of solvents in vacuo gave $130 \mathrm{mg}$ of orange oil, which was purified by flash column chromatography ( $2 \times 15 \mathrm{~cm}$ silica) with $88: 12$ hexanes/EtOAc to yield $59.1 \mathrm{mg}$ $(53 \%)$ of 27 as a clear colorless oil, which solidified overnight $(12 \mathrm{~h})$ to give a beige solid: $\mathrm{mp} 63-65{ }^{\circ} \mathrm{C} ;{ }^{1} \mathrm{H}$ NMR $\left(400 \mathrm{MHz}, \mathrm{CDCl}_{3}\right) \delta 10.32(\mathrm{~s}, 1 \mathrm{H}), 6.56(\mathrm{~d}, J=10.3 \mathrm{~Hz}$, $1 \mathrm{H}), 6.44(\mathrm{~s}, 1 \mathrm{H}), 5.58(\mathrm{~d}, J=10.3 \mathrm{~Hz}, 1 \mathrm{H}), 5.24(\mathrm{~s}, 2 \mathrm{H}), 3.84(\mathrm{~s}, 3 \mathrm{H}), 3.51(\mathrm{~s}, 3 \mathrm{H}), 1.45$ (s, 6H); ${ }^{13} \mathrm{C} \mathrm{NMR}\left(100 \mathrm{MHz}, \mathrm{CDCl}_{3}\right) \delta 187.0,160.9,159.8,158.5,128.2,115.5,112.8$, 109.0, 99.1, 94.6, 77.8, 63.1, 56.5, 28.3; IR $\left(\mathrm{CH}_{2} \mathrm{Cl}_{2}\right) \vee 2984,2938,1680,1594,1567 \mathrm{~cm}^{-}$ ${ }^{1}$; HRMS (ESI) calcd for $\mathrm{C}_{15} \mathrm{H}_{19} \mathrm{O}_{5}\left(\mathrm{MH}^{+}\right)$279.1232, found 279.1228; Anal. Calcd for $\mathrm{C}_{15} \mathrm{H}_{18} \mathrm{O}_{5}$ : C, 64.74; H, 6.52. Found: $\mathrm{C}, 64.59 ; \mathrm{H}, 6.52$. The regiochemistry of 27 was confirmed by NOESY analysis and is shown below in Figures $1 \mathrm{a}$ and $1 \mathrm{~b}$. Also obtained $20.2 \mathrm{mg}(18 \%)$ of the regioisomer of

27 (7-Methoxy-5-(methoxymethoxy)-2,2-dimethyl-2H-1benzopyran-4-carboxaldehyde) as a clear colorless oil: ${ }^{1} \mathrm{H}$ NMR $\left(400 \mathrm{MHz}, \mathrm{CDCl}_{3}\right) \delta 10.36(\mathrm{~s}, 1 \mathrm{H}), 6.56(\mathrm{~d}, J=9.5 \mathrm{~Hz}$, $1 \mathrm{H}), 6.27(\mathrm{~s}, 1 \mathrm{H}), 5.53(\mathrm{~d}, J=9.5 \mathrm{~Hz}, 1 \mathrm{H}), 5.27(\mathrm{~s}, 2 \mathrm{H}), 3.87$

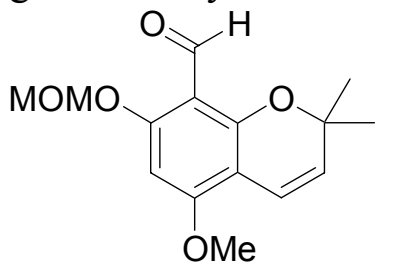
(s, 3H), 3.52 (s, 3H), $1.46(\mathrm{~s}, 6 \mathrm{H}) ;{ }^{13} \mathrm{C}$ NMR $\left(100 \mathrm{MHz}, \mathrm{CDCl}_{3}\right) \delta 187.2,159.9,159.8$, $157.5,126.9,115.7,109.7,104.9,95.0,91.1,77.4,56.5,55.8,27.9$; IR (neat) $\vee 2973$, 2930, 2844, 1680, 1638, $1572 \mathrm{~cm}^{-1} ; \mathrm{m} / \mathrm{z}$ (ESI-MS) $301.07\left(\mathrm{MNa}^{+}\right)$. 


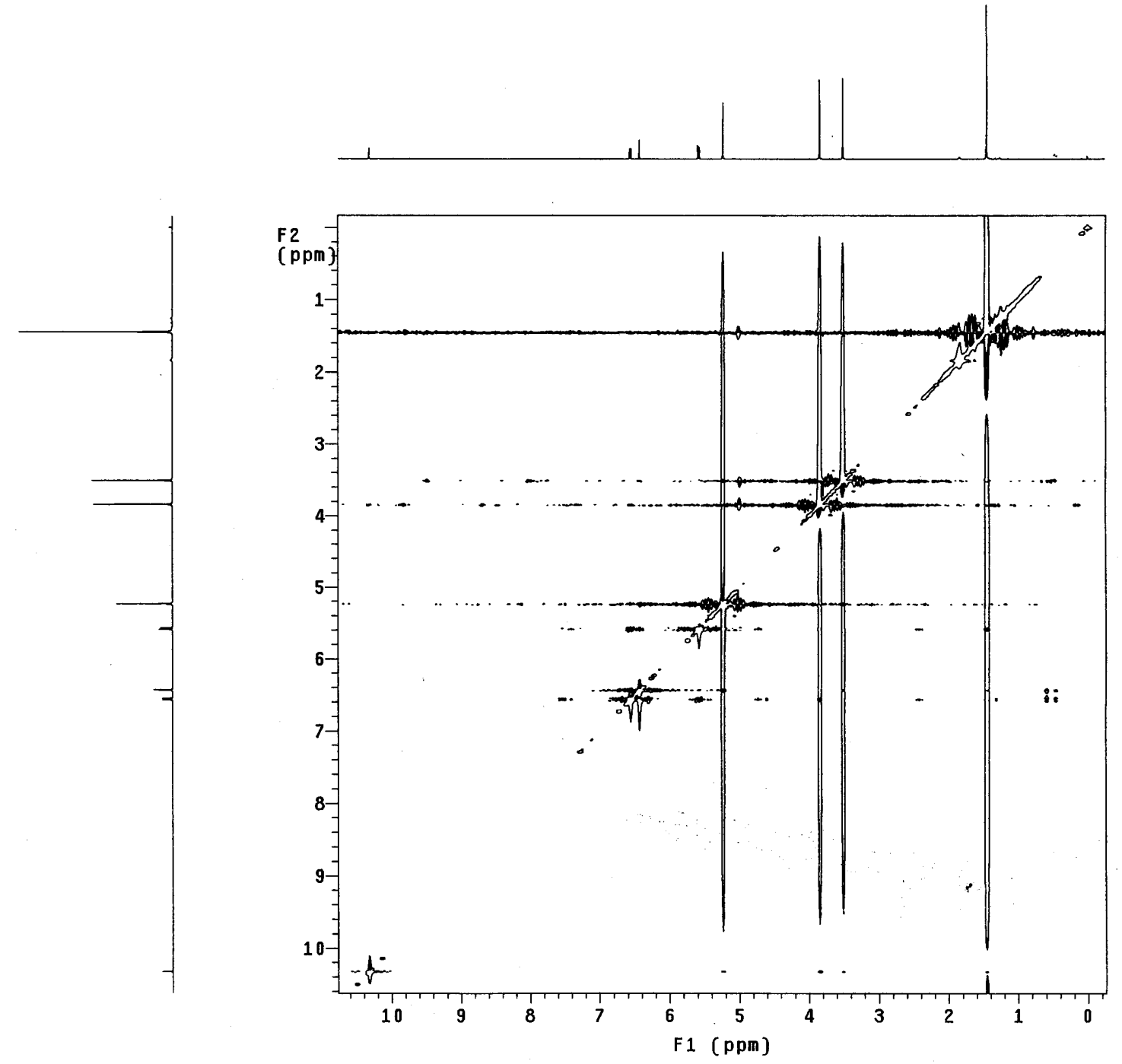

Figure 1a. NOESY spectrum of 27. 


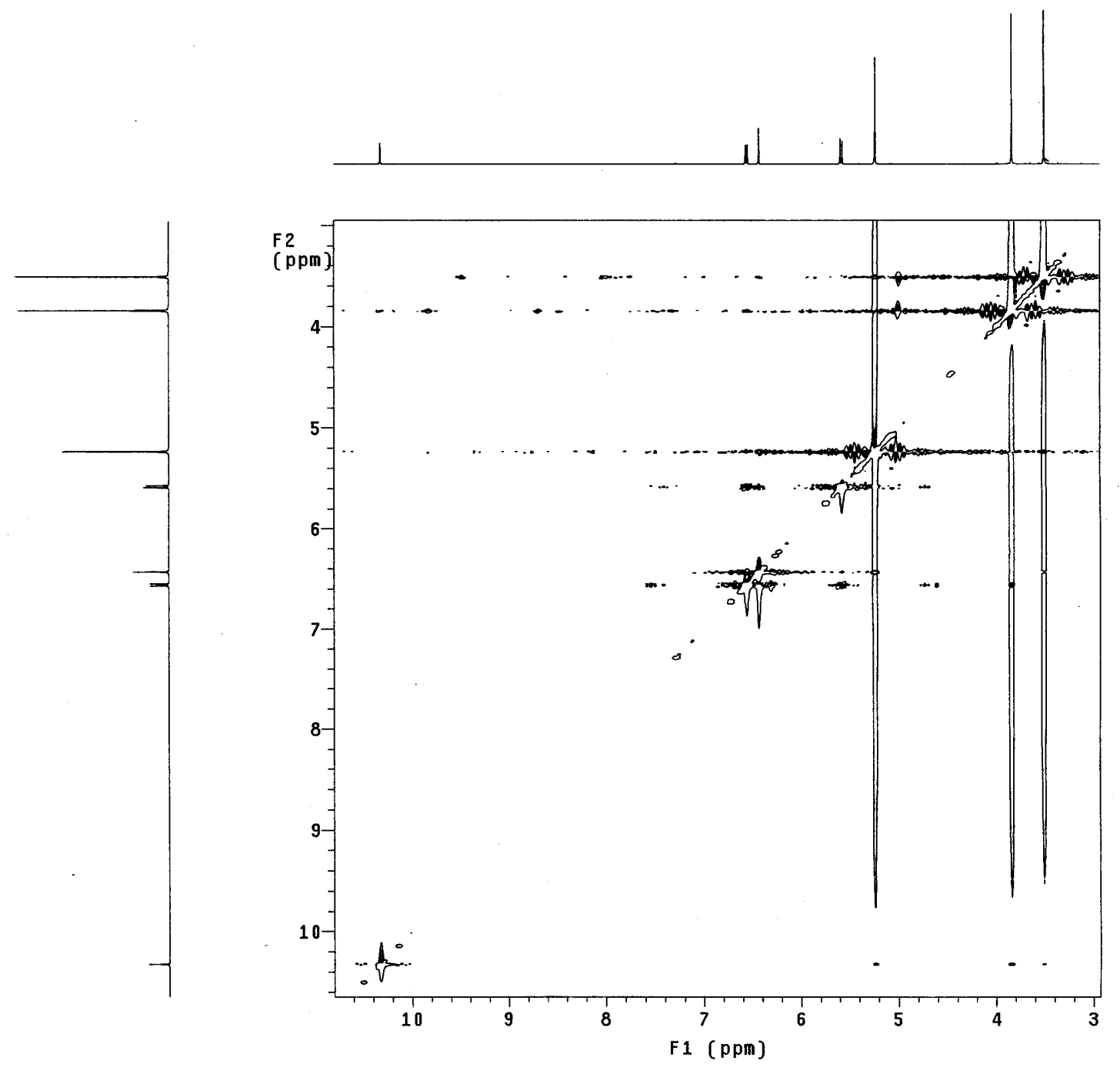

Figure 1b. Expanded NOESY spectrum of 27.

3-Pyridinylcarbamic acid, 1,1-dimethylethyl ester (13). ${ }^{5}$ To a flame-dried $50 \mathrm{~mL}$ round-bottomed flask, purged with argon, was added 3-aminopyridine $\mathrm{N}(1.01 \mathrm{~g}, 10.7 \mathrm{mmol})$ and THF (11.0 mL). NaHMDS (23.5 mL, $1.00 \mathrm{M}$ $\mathrm{NH}$ solution in THF, $23.5 \mathrm{mmol}$ ) was added dropwise over $10 \mathrm{~min}$ and the Boc resulting burgundy solution was stirred for $30 \mathrm{~min}$. A solution of di-tertbutyl dicarbonate $(2.34 \mathrm{~g}, 10.7 \mathrm{mmol})$ in THF $(4.0 \mathrm{~mL})$ was added dropwise over $2 \mathrm{~min}$. After $2 \mathrm{~h}$ the dark red solution was poured into $\mathrm{H}_{2} \mathrm{O}(100 \mathrm{~mL})$ and the mixture was extracted with EtOAc $(3 \times 50 \mathrm{~mL})$. The organic extracts were pooled, washed with $\mathrm{H}_{2} \mathrm{O}$ $(1 \times 50 \mathrm{~mL})$ and saturated $\mathrm{NaCl}$ solution $(1 \times 50 \mathrm{~mL})$, dried with $\mathrm{MgSO}_{4}$ and filtered.

\footnotetext{
${ }^{5}$ Kelly, T. A.; McNeil, D. W. Tetrahedron Lett. 1994, 35, 9003.
} 
Removal of solvents in vacuo gave $2.21 \mathrm{~g}$ of a deep red oil. Purification by flash column chromatography $(5 \times 10 \mathrm{~cm}$ silica) with 60:40 hexanes/EtOAc yielded $1.46 \mathrm{~g}(71 \%)$ of the desired product as a pale orange solid: $\mathrm{mp}$ 94-95 ${ }^{\circ} \mathrm{C}\left[\left(\right.\right.$ lit. $^{6}{ }^{6} 116-117{ }^{\circ} \mathrm{C}$ $\left(\mathrm{Et}_{2} \mathrm{O} /\right.$ pentane) $] ;{ }^{1} \mathrm{H}$ NMR $\left(400 \mathrm{MHz}, \mathrm{CDCl}_{3}\right) \delta 8.44(\mathrm{~d}, J=1.8 \mathrm{~Hz}, 1 \mathrm{H}), 8.29(\mathrm{dd}, J=$ 4.7, $1.8 \mathrm{~Hz}, 1 \mathrm{H}$ ), 7.99 (br d, $J=7.9 \mathrm{~Hz}, 1 \mathrm{H}$ ), 7.24 (dd, $J=7.9,4.7 \mathrm{~Hz}, 1 \mathrm{H}$ ), 6.70 (br s, $1 \mathrm{H}), 1.53(\mathrm{~s}, 9 \mathrm{H}) ;{ }^{13} \mathrm{C}$ NMR $\left(100 \mathrm{MHz}, \mathrm{CDCl}_{3}\right) \delta 152.8,143.3,139.7,135.7,125.6$, 123.5, 80.8, 28.3; $\mathrm{m} / z$ (ESI-MS) $195.09\left(\mathrm{MH}^{+}\right)$; Anal. Calcd for $\mathrm{C}_{10} \mathrm{H}_{14} \mathrm{~N}_{2} \mathrm{O}_{2}$ : C, 61.84; H, 7.27; N, 14.42. Found: C, 61.83; H, 7.34; N, 14.39.

\section{4-\{Hydroxy [5-methoxy-7-(methoxymethoxy)-2,2-dimethyl-2H-benzopyran-6-}

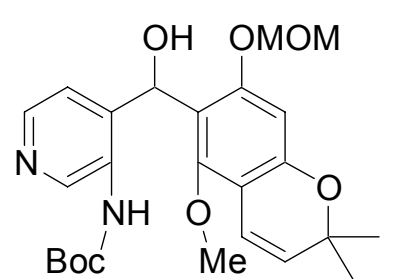

yl]methyl\}-3-pyridinylcarbamic acid, 1,1-dimethylethyl ester (28). To a flame-dried, $15 \mathrm{~mL}$ round-bottomed flask, purged with argon, was added pyridine 13 (141 $\mathrm{mg}, 0.728 \mathrm{mmol})$ and THF $(3.0 \mathrm{~mL})$. The pale yellow solution was cooled to $-78{ }^{\circ} \mathrm{C}$ $\left(\mathrm{CO}_{2}\right.$ /acetone bath) and ${ }^{t} \mathrm{BuLi}(0.940 \mathrm{~mL}, 1.67 \mathrm{M}$ solution in pentane, $1.57 \mathrm{mmol}$ ) was added dropwise over $5 \mathrm{~min}$. The resulting deep red/orange solution was stirred for $2 \mathrm{~h}$ at $-78{ }^{\circ} \mathrm{C}$ and then aldehyde 27 (198 $\mathrm{mg}, 0.713 \mathrm{mmol})$ was added via cannula over $1 \mathrm{~min}$, as a solution in THF $(2 \mathrm{~mL})$. The reaction mixture was stirred for $0.5 \mathrm{~h}$ at $-78{ }^{\circ} \mathrm{C}$, then allowed to warm to room temperature and stir for an additional $1.5 \mathrm{~h}$. The reaction was quenched with saturated $\mathrm{NH}_{4} \mathrm{Cl}$ solution (ca. $\left.5 \mathrm{~mL}\right)$, diluted with $\mathrm{H}_{2} \mathrm{O}(20 \mathrm{~mL})$ and extracted with EtOAc $(3 \times 30$ $\mathrm{mL})$. The organic extracts were pooled, washed with $\mathrm{H}_{2} \mathrm{O}(1 \times 30 \mathrm{~mL})$ and saturated $\mathrm{NaCl}$ solution $(1 \times 30 \mathrm{~mL})$, dried with $\mathrm{MgSO}_{4}$ and filtered. Removal of solvents in vacuo gave $383 \mathrm{mg}$ of a pale orange foam. Purification by flash column chromatography $(2.5 \mathrm{x}$ $15 \mathrm{~cm}$ silica) with 55:45 EtOAc/hexanes yielded $214 \mathrm{mg}(63 \%)$ of 28 as a white foam: mp $73-76{ }^{\circ} \mathrm{C}$ (a small amount was ground to a fine powder with a mortar and pestle); ${ }^{1} \mathrm{H}$ NMR (400 MHz, $\left.\mathrm{CDCl}_{3}\right) \delta 9.24($ br s, $1 \mathrm{H}), 8.35($ br s, $1 \mathrm{H}), 8.12(\mathrm{~d}, J=4.8 \mathrm{~Hz}, 1 \mathrm{H}), 6.88$ $(\mathrm{d}, J=4.8 \mathrm{~Hz}, 1 \mathrm{H}), 6.50(\mathrm{~s}, 1 \mathrm{H}), 6.47(\mathrm{~d}, J=10.3 \mathrm{~Hz}, 1 \mathrm{H}), 6.16(\mathrm{br} \mathrm{s}, 1 \mathrm{H}), 5.58(\mathrm{~d}, J=$ $10.3 \mathrm{~Hz}, 1 \mathrm{H}), 5.12(\mathrm{~d}, J=6.6 \mathrm{~Hz}, 1 \mathrm{H}), 5.06(\mathrm{~d}, J=6.6 \mathrm{~Hz}, 1 \mathrm{H}), 4.67(\mathrm{br} \mathrm{s}, 1 \mathrm{H}), 3.63$ (s, $3 \mathrm{H}), 3.27(\mathrm{~s}, 3 \mathrm{H}), 1.54(\mathrm{~s}, 9 \mathrm{H}), 1.47(\mathrm{~s}, 3 \mathrm{H}), 1.43(\mathrm{~s}, 3 \mathrm{H}) ;{ }^{13} \mathrm{C} \mathrm{NMR}\left(100 \mathrm{MHz}, \mathrm{CDCl}_{3}\right) \delta$ $155.3,154.8,154.4,152.5,142.9,142.2,139.0,134.1,128.3,120.6,116.3,113.3,108.9$, 99.4, 94.3, 80.4, 76.5, 66.5, 62.9, 56.4, 28.4, 28.2, 27.7; HRMS (ESI) calcd for $\mathrm{C}_{25} \mathrm{H}_{33} \mathrm{~N}_{2} \mathrm{O}_{7}\left(\mathrm{MH}^{+}\right)$473.2288, found 473.2274.

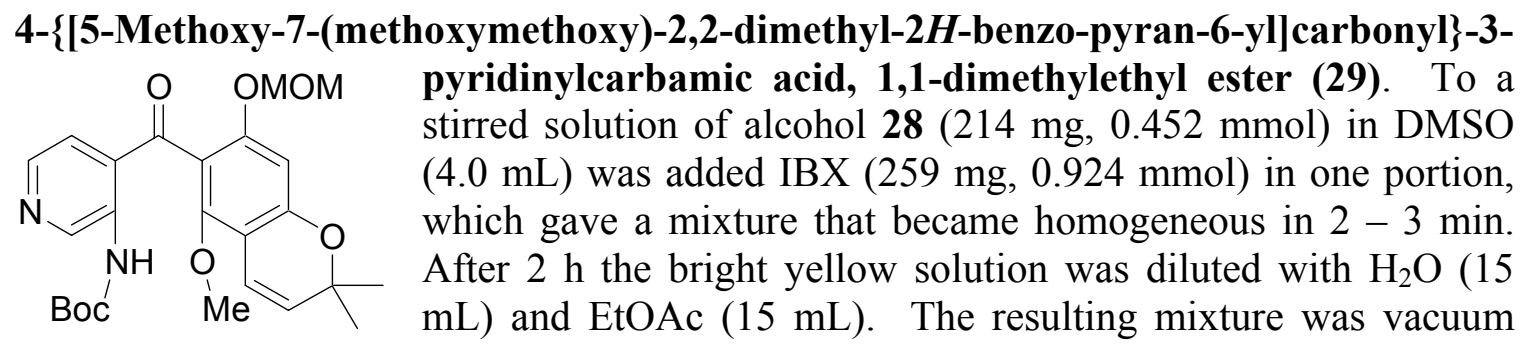
filtered through a pad of celite directly into a separatory funnel and the pad was washed with EtOAc $(2 \times 15 \mathrm{~mL})$. The layers were separated and the aqueous layer extracted with

\footnotetext{
${ }^{6}$ Venuti, M. C.; Stephenson, R. A.; Alvarez, R.; Bruno, J. J.; Strosberg, A. M. J. Med. Chem. 1988, 31, 2136.
} 
EtOAc $(1 \times 30 \mathrm{~mL})$. The organic phases were pooled, washed with $\mathrm{H}_{2} \mathrm{O}(3 \times 15 \mathrm{~mL})$ and saturated $\mathrm{NaCl}$ solution (1 x $30 \mathrm{~mL}$ ), dried with $\mathrm{MgSO}_{4}$ and filtered. Removal of solvents in vacuo gave $237 \mathrm{mg}$ of a yellow oil. Purification by passing through a plug of silica $(2 \times 3 \mathrm{~cm})$ with $80: 20$ hexanes/EtOAc yielded $188 \mathrm{mg}(88 \%)$ of the product as a yellow foam: $\mathrm{mp} 52-54{ }^{\circ} \mathrm{C}$ (a small amount was ground to a fine powder with a mortar and pestle); ${ }^{1} \mathrm{H}$ NMR $\left(400 \mathrm{MHz}, \mathrm{CDCl}_{3}\right) \delta 10.41(\mathrm{~s}, 1 \mathrm{H}), 9.85(\mathrm{~s}, 1 \mathrm{H}), 8.29(\mathrm{~d}, J=5.1$ $\mathrm{Hz}, 1 \mathrm{H}), 7.31(\mathrm{~d}, J=5.1 \mathrm{~Hz}, 1 \mathrm{H}), 6.48(\mathrm{~d}, J=10.3 \mathrm{~Hz}, 1 \mathrm{H}), 6.48(\mathrm{~s}, 1 \mathrm{H}), 5.60(\mathrm{~d}, J=$ $10.3 \mathrm{~Hz}, 1 \mathrm{H}), 4.99(\mathrm{~s}, 2 \mathrm{H}), 3.69(\mathrm{~s}, 3 \mathrm{H}), 3.25(\mathrm{~s}, 3 \mathrm{H}), 1.57(\mathrm{~s}, 9 \mathrm{H}), 1.47(\mathrm{~s}, 6 \mathrm{H}) ;{ }^{13} \mathrm{C} \mathrm{NMR}$ $\left(100 \mathrm{MHz}, \mathrm{CDCl}_{3}\right) \delta 197.9,156.4,154.9,154.3,152.3,142.4,142.2,135.6,128.4,126.8$, $124.4,115.9,115.2,108.8,98.9,94.3,81.2,76.9$ (overlaps with middle peak of $\mathrm{CDCl}_{3}$ triplet), 63.4, 56.3, 28.3, 28.1; IR $\left(\mathrm{CCl}_{4}\right) \vee 3299,2976,2934,1731,1657,1599,1563$, $1505 \mathrm{~cm}^{-1}$; HRMS (ESI) calcd for $\mathrm{C}_{25} \mathrm{H}_{31} \mathrm{~N}_{2} \mathrm{O}_{7}\left(\mathrm{MH}^{+}\right)$471.2131, found 471.2130; Anal. Calcd for $\mathrm{C}_{25} \mathrm{H}_{30} \mathrm{~N}_{2} \mathrm{O}_{7}$ : C, 63.82; H, 6.43; N, 5.95. Found: C, 63.82; H, 6.57; N, 5.68.

\section{3,12-Dihydro-6-hydroxy-3,3,12-trimethyl-7H-[1]benzopyrano[5,6-b][1,7]naphthyri-}

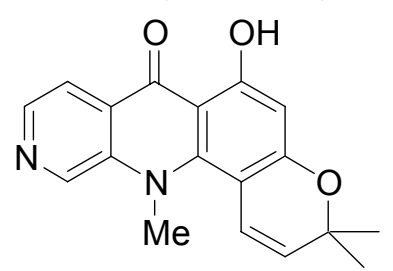

din-7-one [Azacridone-A (1)]. To a flame-dried $10 \mathrm{~mL}$ roundbottomed flask, purged with argon, was added ketone $29(90.7$ $\mathrm{mg}, 0.193 \mathrm{mmol})$ and DMF $(2.0 \mathrm{~mL})$. $\mathrm{NaH}(7.4 \mathrm{mg}, 60 \%$ dispersion in mineral oil, $0.31 \mathrm{mmol}$ ) was added in one portion and the reaction mixture was stirred for $1 \mathrm{~h}$. The resulting bright yellow solution was cooled to $0{ }^{\circ} \mathrm{C}$ (ice/water bath) and $\mathrm{MeI}$ $(13.5 \mu \mathrm{L}, 0.217 \mathrm{mmol})$ was added in one portion via syringe. The reaction mixture was stirred for $10 \mathrm{~min}$ at $0{ }^{\circ} \mathrm{C}$, then allowed to warm to room temperature. After $3 \mathrm{~h}$, the reaction was poured into $\mathrm{H}_{2} \mathrm{O}(20 \mathrm{~mL})$ and extracted with EtOAc $(3 \times 20 \mathrm{~mL})$. The organic extracts were pooled, washed with $\mathrm{H}_{2} \mathrm{O}(1 \times 20 \mathrm{~mL})$ and saturated $\mathrm{NaCl}$ solution ( 1 x $20 \mathrm{~mL}$ ), dried with $\mathrm{MgSO}_{4}$ and filtered. Removal of solvents in vacuo gave $85.1 \mathrm{mg}$ of an orange wax. The crude wax was dissolved in undried dichloroethane $(3 \mathrm{~mL})$ and TFA ( $1 \mathrm{~mL})$ was added. The brown reaction mixture was stirred at room temperature for $1 \mathrm{~h}$ and then a reflux condenser was attached to the flask and the reaction was heated at reflux ( $\sim 90{ }^{\circ} \mathrm{C}$ oil bath) for $12 \mathrm{~h}$ open to air. After cooling to room temperature, the solvents were removed in vacuo and the resulting brown residue was partitioned between saturated $\mathrm{NaHCO}_{3}$ solution $(10 \mathrm{~mL})$ and EtOAc $(20 \mathrm{~mL})$. The aqueous phase was separated and extracted with EtOAc $(2 \times 20 \mathrm{~mL})$. The organic phase and extracts were pooled, washed with saturated $\mathrm{NaCl}$ solution $(1 \times 20 \mathrm{~mL})$, dried with $\mathrm{MgSO}_{4}$ and filtered. Removal of solvents in vacuo gave $65.4 \mathrm{mg}$ of a red/brown solid, which was purified by preparative TLC with EtOAc (developed plate 3 times) to yield $32.7 \mathrm{mg}$ (55\% over two steps) of azacridone-A (1) as a yellow/orange solid: mp 197-200 ${ }^{\circ} \mathrm{C}$ (dec); ${ }^{1} \mathrm{H}$ NMR (400 MHz, acetone- $\left.\mathrm{d}_{6}\right) \delta 14.34(\mathrm{~s}, 1 \mathrm{H}), 9.20(\mathrm{~s}, 1 \mathrm{H}), 8.55(\mathrm{~d}, J=4.9 \mathrm{~Hz}, 1 \mathrm{H}), 8.07(\mathrm{~d}, J=4.9$ $\mathrm{Hz}, 1 \mathrm{H}), 6.83$ (d, $J=9.8 \mathrm{~Hz}, 1 \mathrm{H}), 6.18(\mathrm{~s}, 1 \mathrm{H}), 5.68(\mathrm{~d}, J=9.8 \mathrm{~Hz}, 1 \mathrm{H}), 4.14(\mathrm{~s}, 3 \mathrm{H})$, $1.54(\mathrm{~s}, 6 \mathrm{H}) ;{ }^{13} \mathrm{C}$ NMR $\left(100 \mathrm{MHz}\right.$, acetone- $\left.\mathrm{d}_{6}\right)$ 180.8, 165.5, 163.0, 145.1, 141.9, 141.7, 140.4, 126.4, 124.1, 121.9, 117.6, 108.3, 102.3, 98.3, 77.6, 43.9, 27.1; HRMS (ESI) calc for $\mathrm{C}_{18} \mathrm{H}_{17} \mathrm{~N}_{2} \mathrm{O}_{3}\left(\mathrm{MH}^{+}\right)$309.1239, found 309.1237. 
Procedure for $\mathbf{D}_{2} \mathbf{O}$-quench Study of 5. A $5 \mathrm{~mL}$ round-bottomed flask, containing chromene $5(27.1 \mathrm{mg}, 0.108 \mathrm{mmol})$, was flame dried under vacuum and purged with argon. $\mathrm{Et}_{2} \mathrm{O}(1.0 \mathrm{~mL})$ was added and the solution was cooled to $0{ }^{\circ} \mathrm{C}$. ${ }^{n} \mathrm{BuLi}(0.052 \mathrm{~mL}$, $2.50 \mathrm{M}$ solution in hexane, $0.130 \mathrm{mmol}$ ) was added in one portion and the reaction mixture was allowed to stir for $1 \mathrm{~h} . \mathrm{D}_{2} \mathrm{O}(0.20 \mathrm{~mL})$ was added and the reaction was allowed to warm to room temperature. After $10 \mathrm{~min}$, the reaction mixture was diluted with $\mathrm{H}_{2} \mathrm{O}(10 \mathrm{~mL})$ and extracted with EtOAc $(1 \times 30 \mathrm{~mL})$. The organic phase was dried with $\mathrm{MgSO}_{4}$, filtered, solvents were removed in vacuo, and a ${ }^{1} \mathrm{H}$ NMR $(400 \mathrm{MHz}$, $\mathrm{CDCl}_{3}$ ) was taken. The regioselectivity and extent of lithiation were determined by comparing the integration values of the aromatic protons with those of non-deuterated starting material. Peak assignment: The aromatic protons were assigned by NOESY analysis of 5. The diagnostic nOe's are shown below in Figure 2 and the NOESY spectrum is shown in Figures $3 a$ and $3 b$.

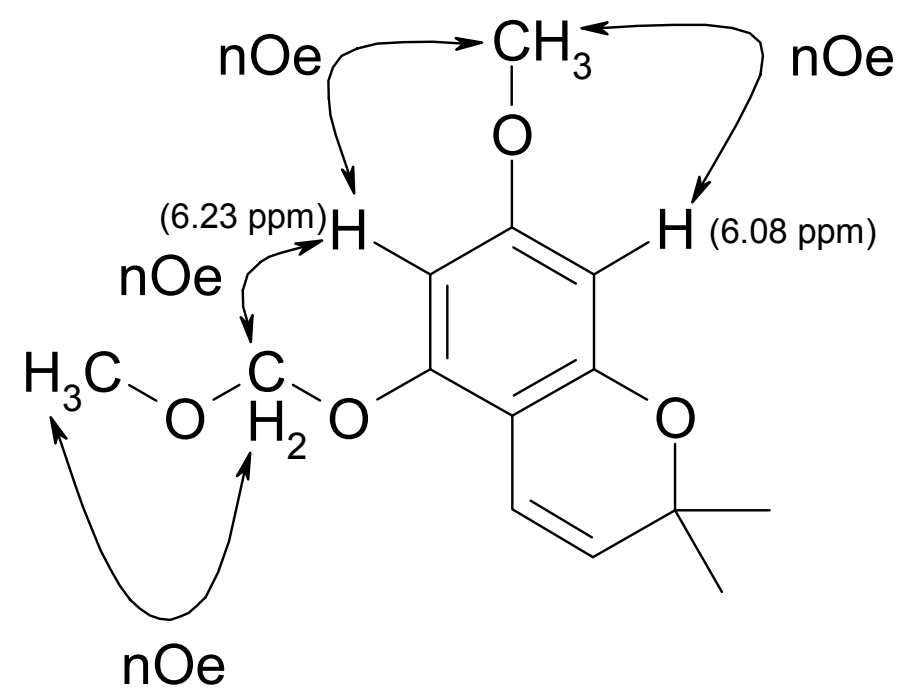

Figure 2. Diagnostic nOe cross peaks observed in NOESY analysis of 5. The proton at $6.23 \mathrm{ppm}$ shows $>90 \%$ deuterium incorporation by integration. 


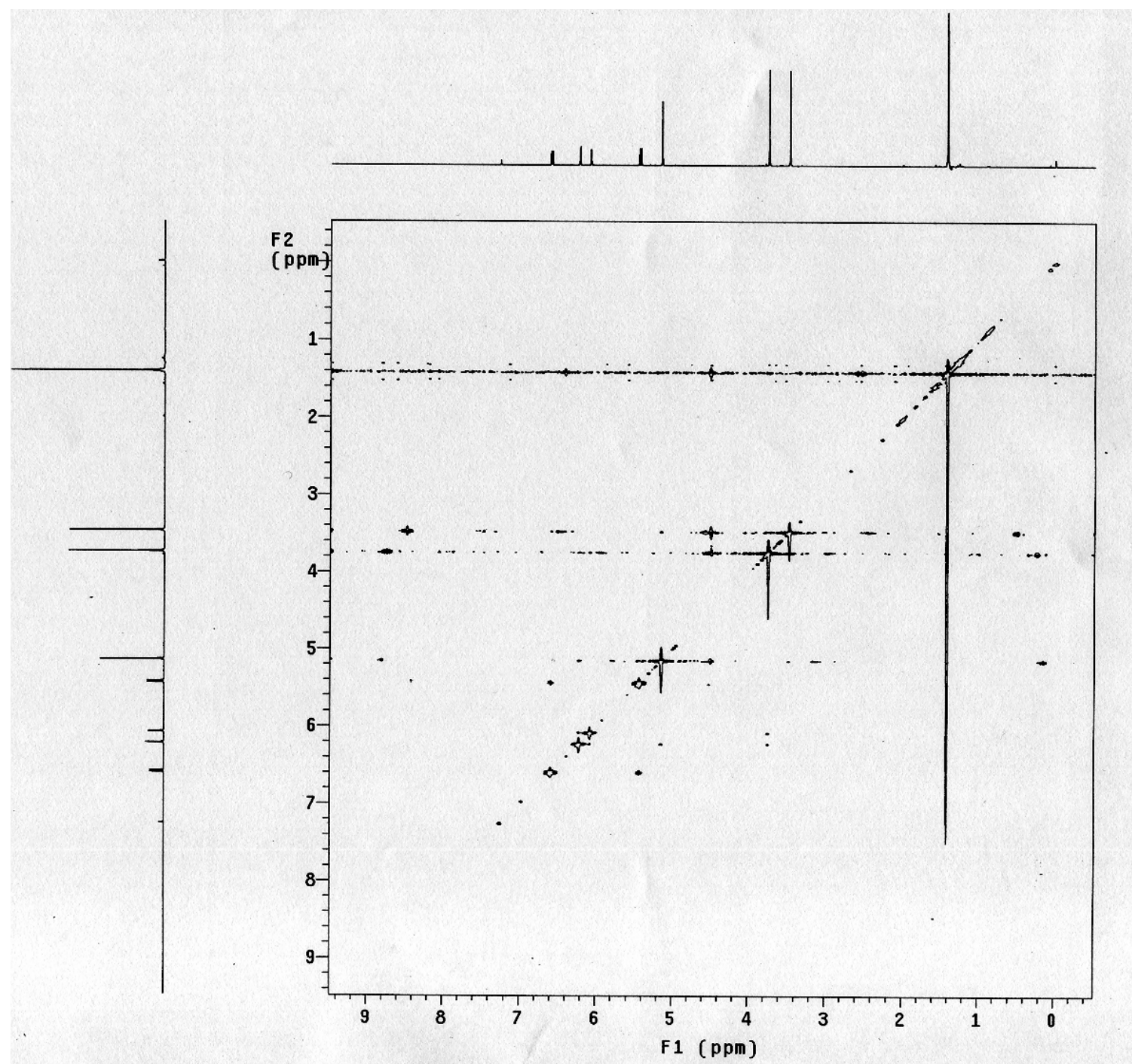

Figure 3a. NOESY spectrum of $\mathbf{5}$. 


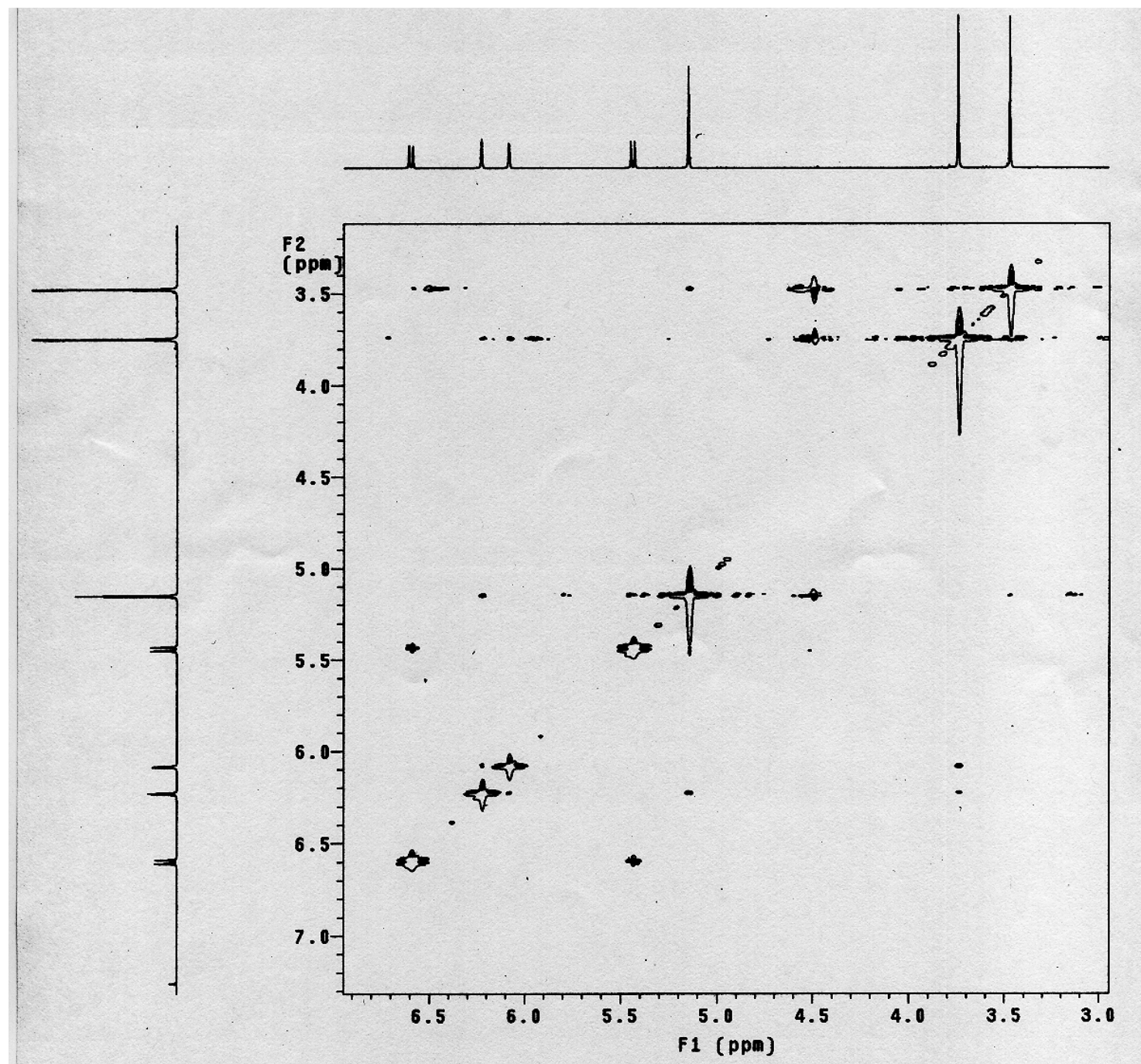

Figure 3b. Expanded NOESY spectrum of $\mathbf{5}$. 
General Procedure for $\mathbf{D}_{2} \mathbf{O}$-quench Studies of 24. A $5 \mathrm{~mL}$ round-bottomed flask, containing chromene $24(0.100 \mathrm{mmol})$, was flame dried under vacuum and purged with argon. Then solvent and additive (if used) were added and the flask was cooled to $0{ }^{\circ} \mathrm{C}$. The base (1.2 equiv.) was added, the reaction stirred for one $\mathrm{h}$ and then quenched with $\mathrm{D}_{2} \mathrm{O}(0.2 \mathrm{~mL})$. After warming to room temperature and stirring for 5-10 min, the reaction mixture was worked up and analyzed as described above. Diagnostic nOe's are shown below in Figure 4, the data for selected experiments are shown in Table 1 and the NOESY spectrum is shown in Figures $5 \mathrm{a}$ and $5 \mathrm{~b}$.

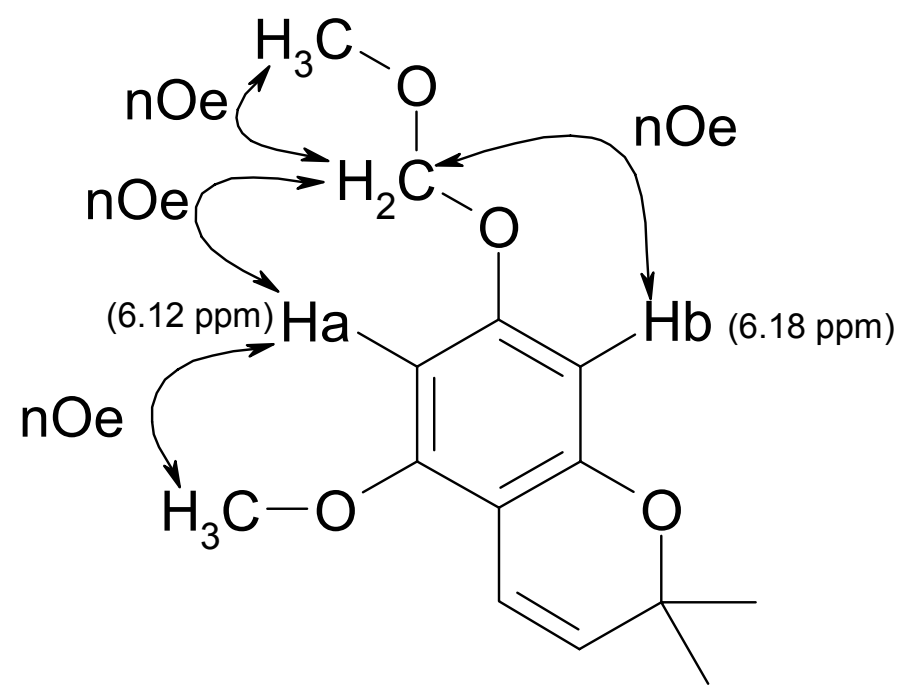

Figure 4. Diagnostic nOe cross peaks observed in NOESY analysis of $\mathbf{2 4 .}$

\begin{tabular}{|c|c|c|c|c|c|c|}
\hline \multirow{2}{*}{ Entry } & \multirow{2}{*}{ Solvent } & $\begin{array}{c}{[\mathrm{M}] \text { of }} \\
24\end{array}$ & Base & \multirow{2}{*}{ Additive (Eq.) } & \multicolumn{2}{|c|}{$\mathbf{D}$ Incorporation } \\
\hline 1 & $\mathrm{Et}_{2} \mathrm{O}$ & 0.1 & nBuLi & none & 17 & 49 \\
\hline 2 & $\mathrm{Et}_{2} \mathrm{O}$ & 0.1 & nBuLi & TMEDA (1.2) & 38 & 53 \\
\hline 3 & $\mathrm{Et}_{2} \mathrm{O}$ & 0.1 & nBuLi & HMPA (2.0) & 44 & 16 \\
\hline 4 & $\mathrm{Et}_{2} \mathrm{O}$ & 0.1 & nBuLi & HMPA (6.2) & 35 & 16 \\
\hline 5 & $\mathrm{THF}$ & 0.1 & nBuLi & none & 27 & 58 \\
\hline 6 & $\mathrm{THF}$ & 0.1 & nBuLi & TMEDA (1.2) & 33 & 57 \\
\hline 7 & $\mathrm{THF}$ & 0.1 & nBuLi & HMPA (1.2) & 55 & 23 \\
\hline 8 & $\mathrm{THF}$ & 0.1 & nBuLi & HMPA (2.0) & 54 & 16 \\
\hline 9 & $\mathrm{THF}$ & 0.2 & nBuLi & HMPA (2.0) & 70 & 17 \\
\hline
\end{tabular}

Table 1. Selected data for $\mathrm{D}_{2} \mathrm{O}$-quench studies of 24. Percent deuterium (D) incorporation was determined from the integration in the ${ }^{1} \mathrm{H}$ NMR (400 MHz, $\mathrm{CDCl}_{3}$ ). 


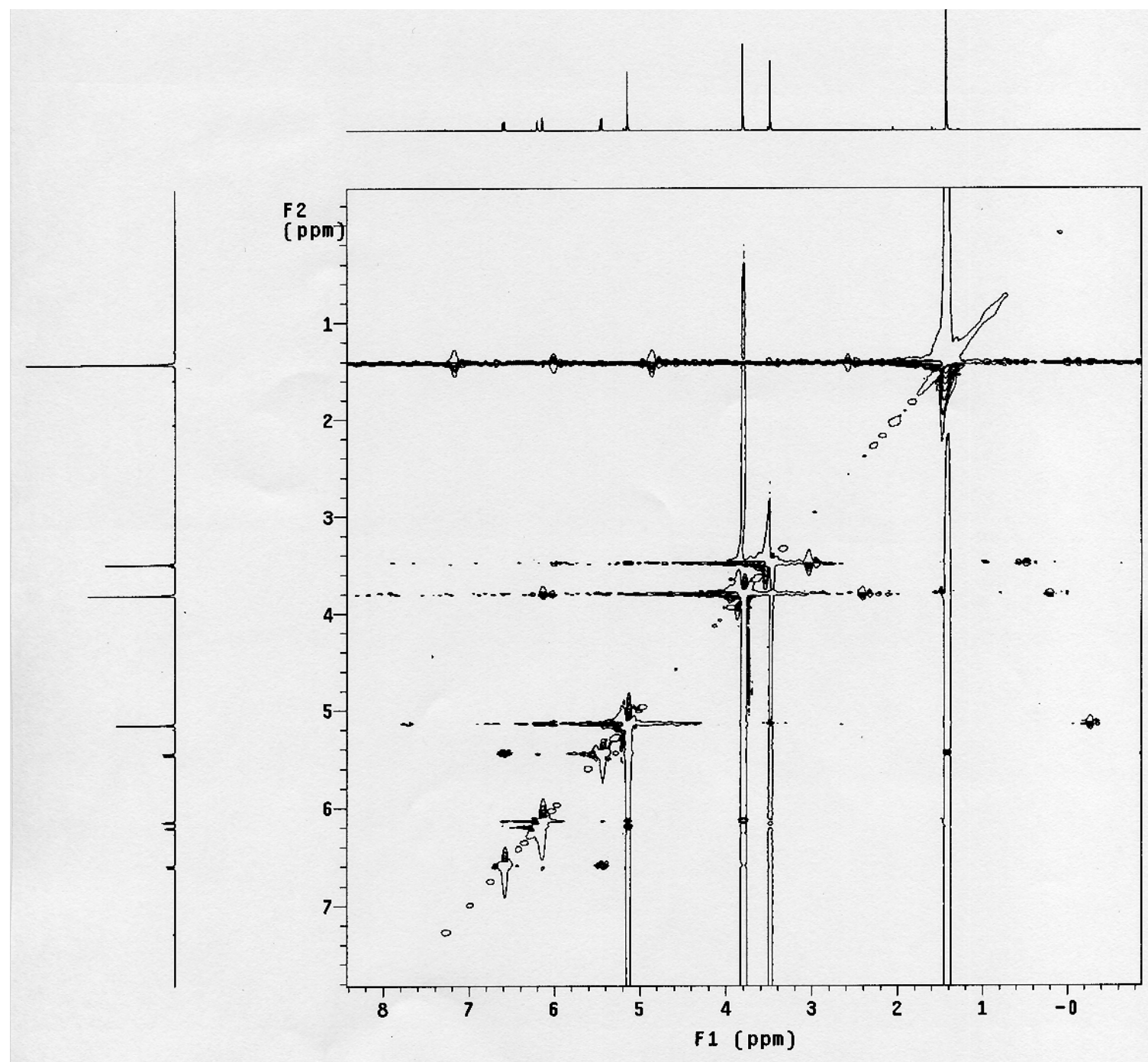

Figure 5a. NOESY spectrum of 24. 


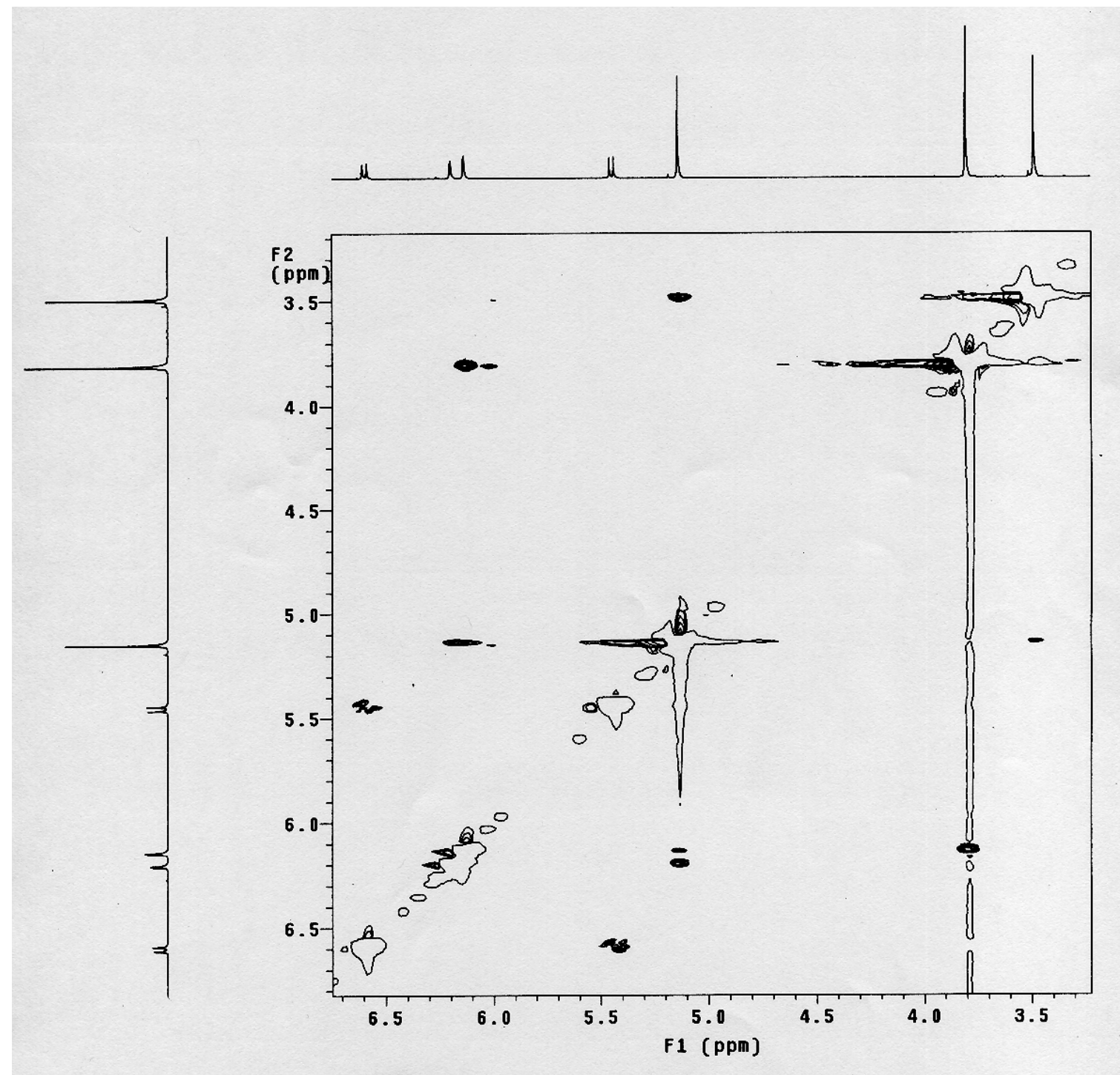

Figure 5b. Expanded NOESY spectrum of 24. 


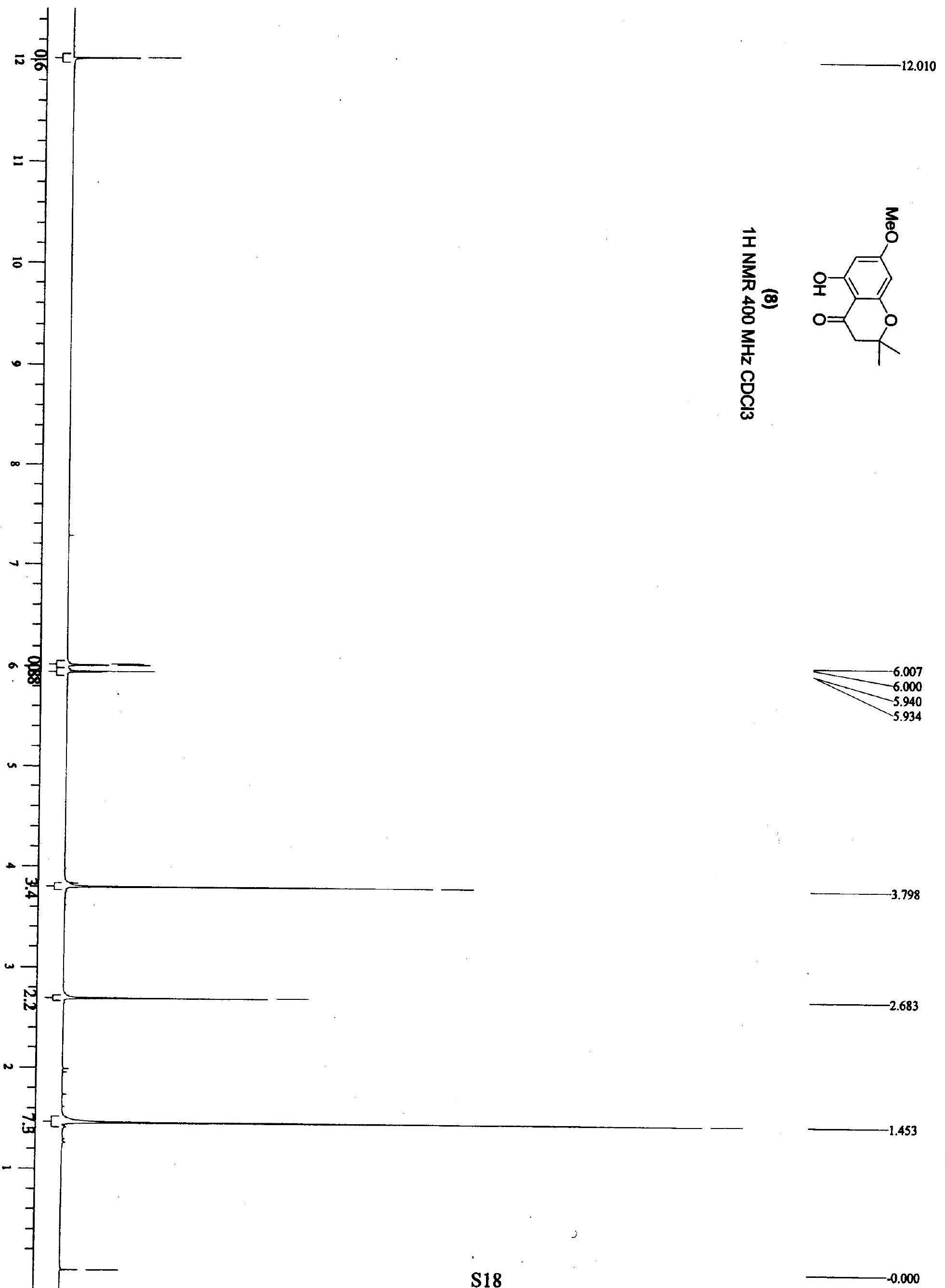




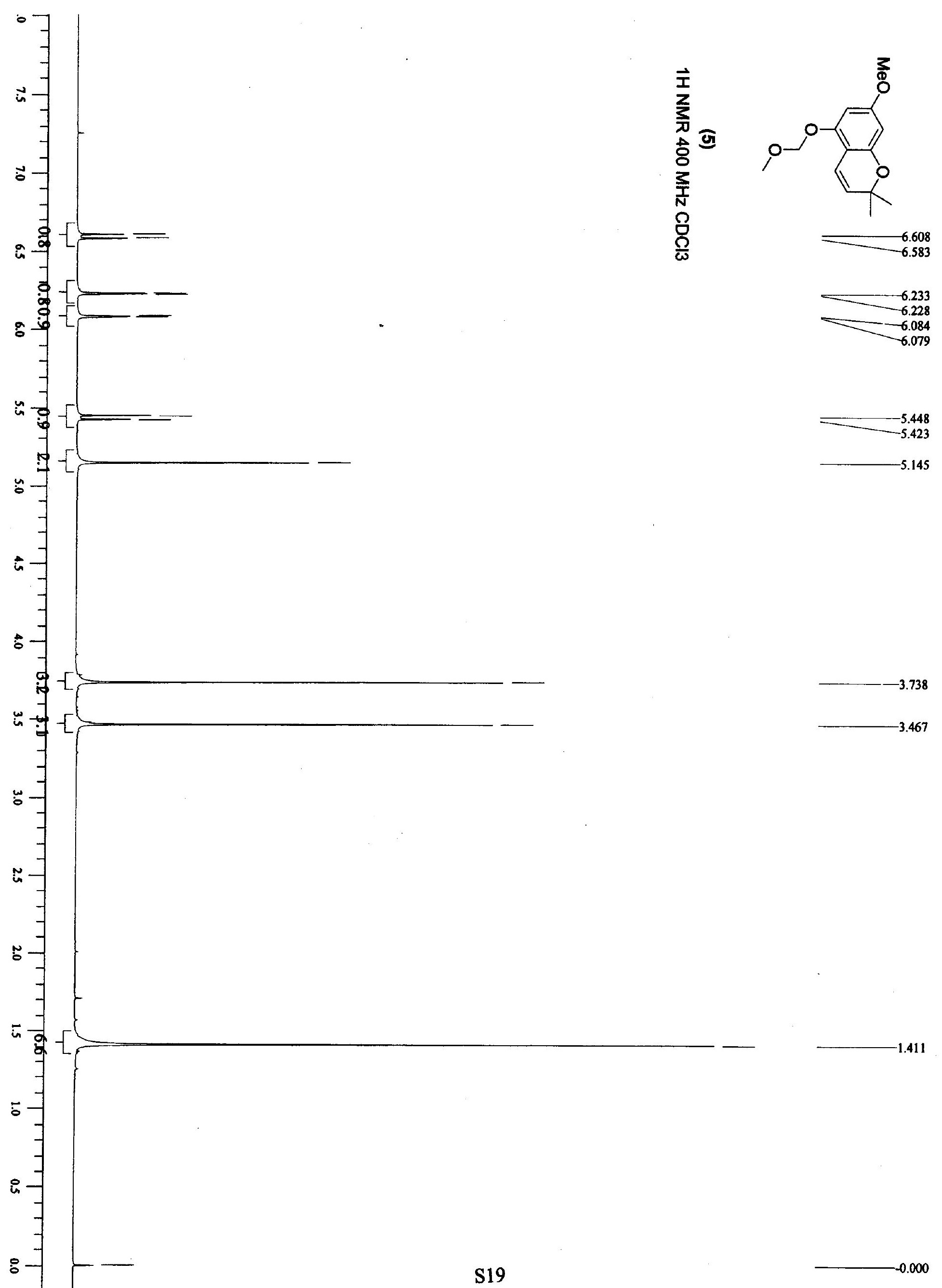



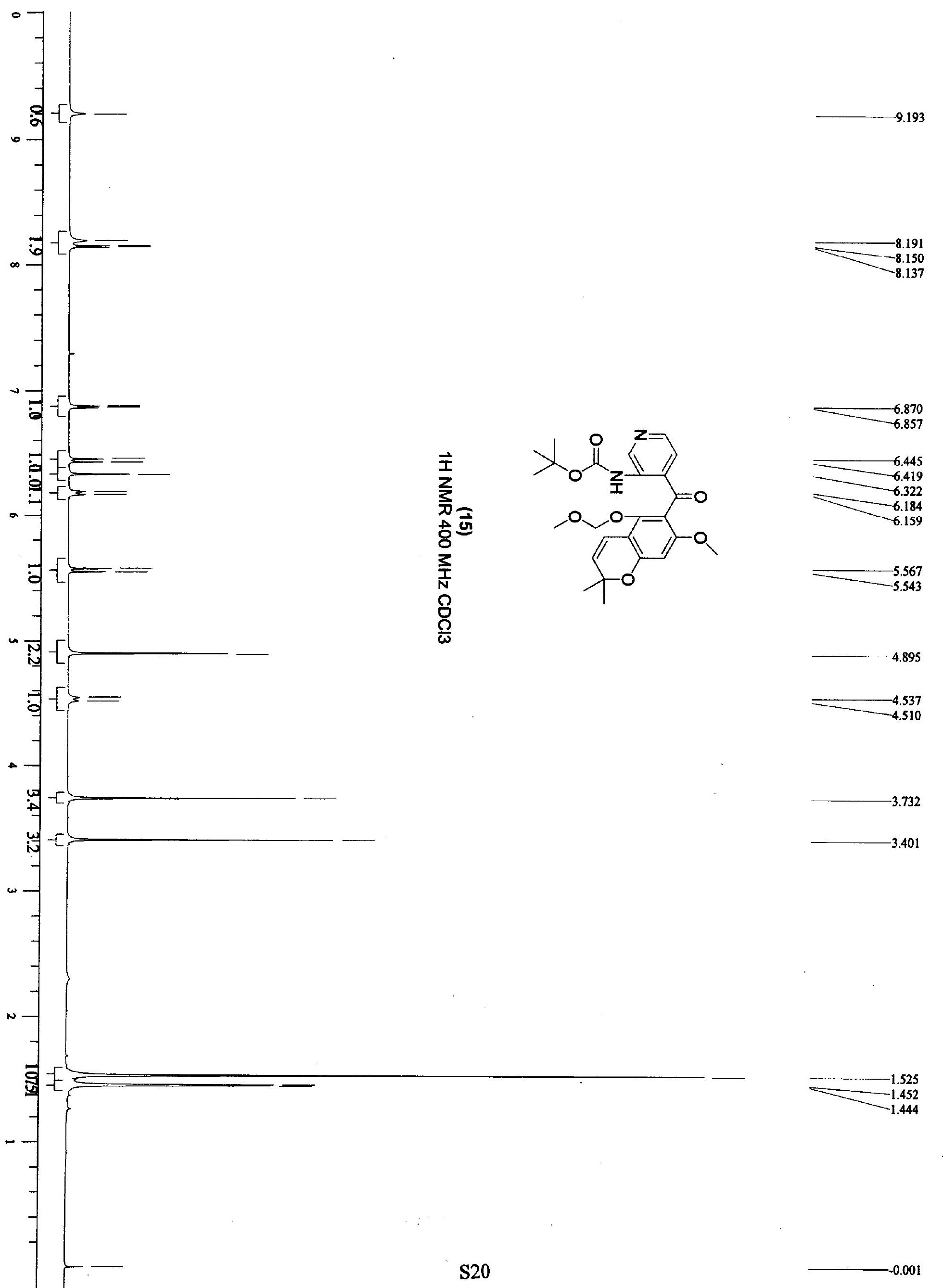


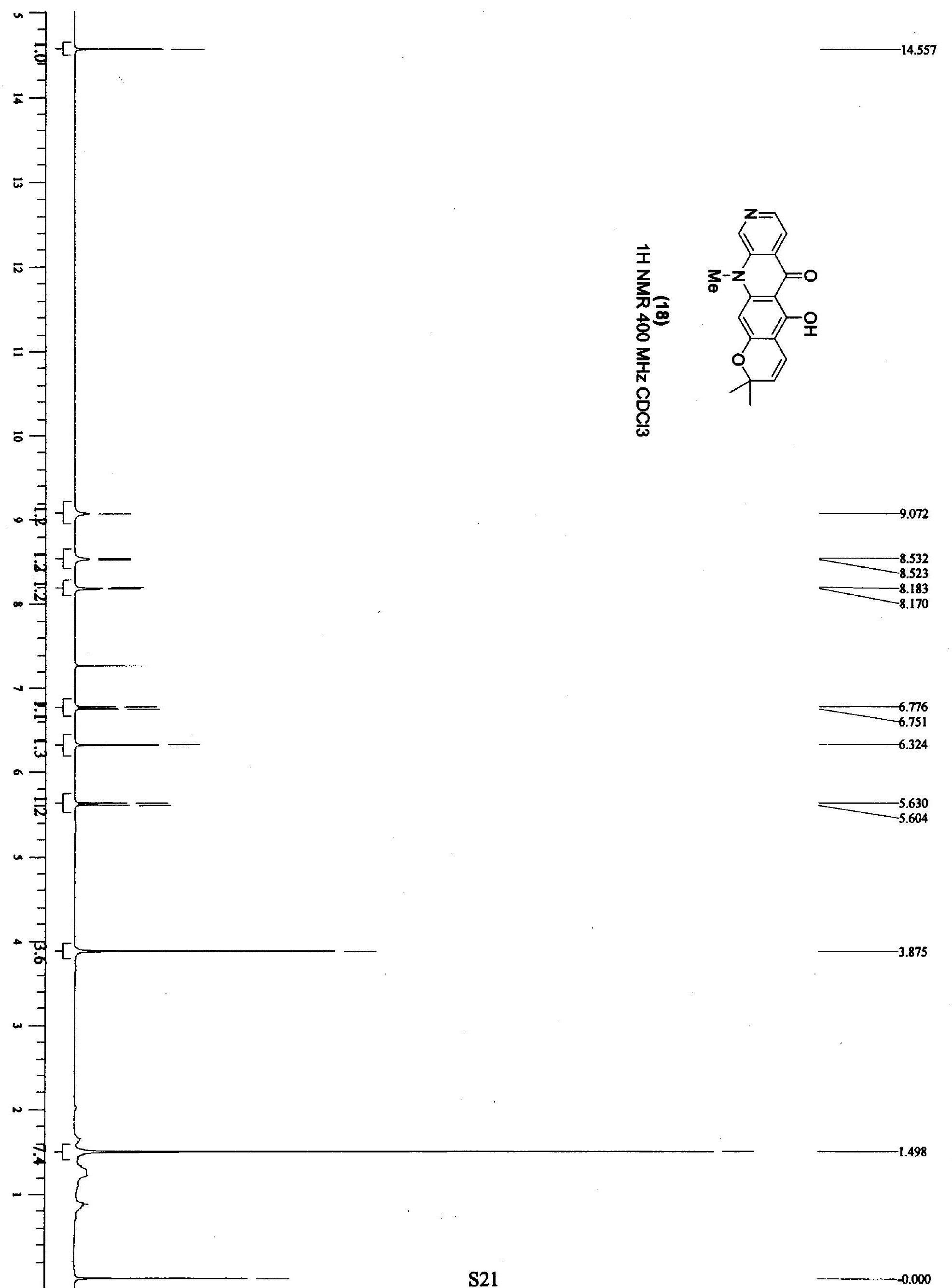




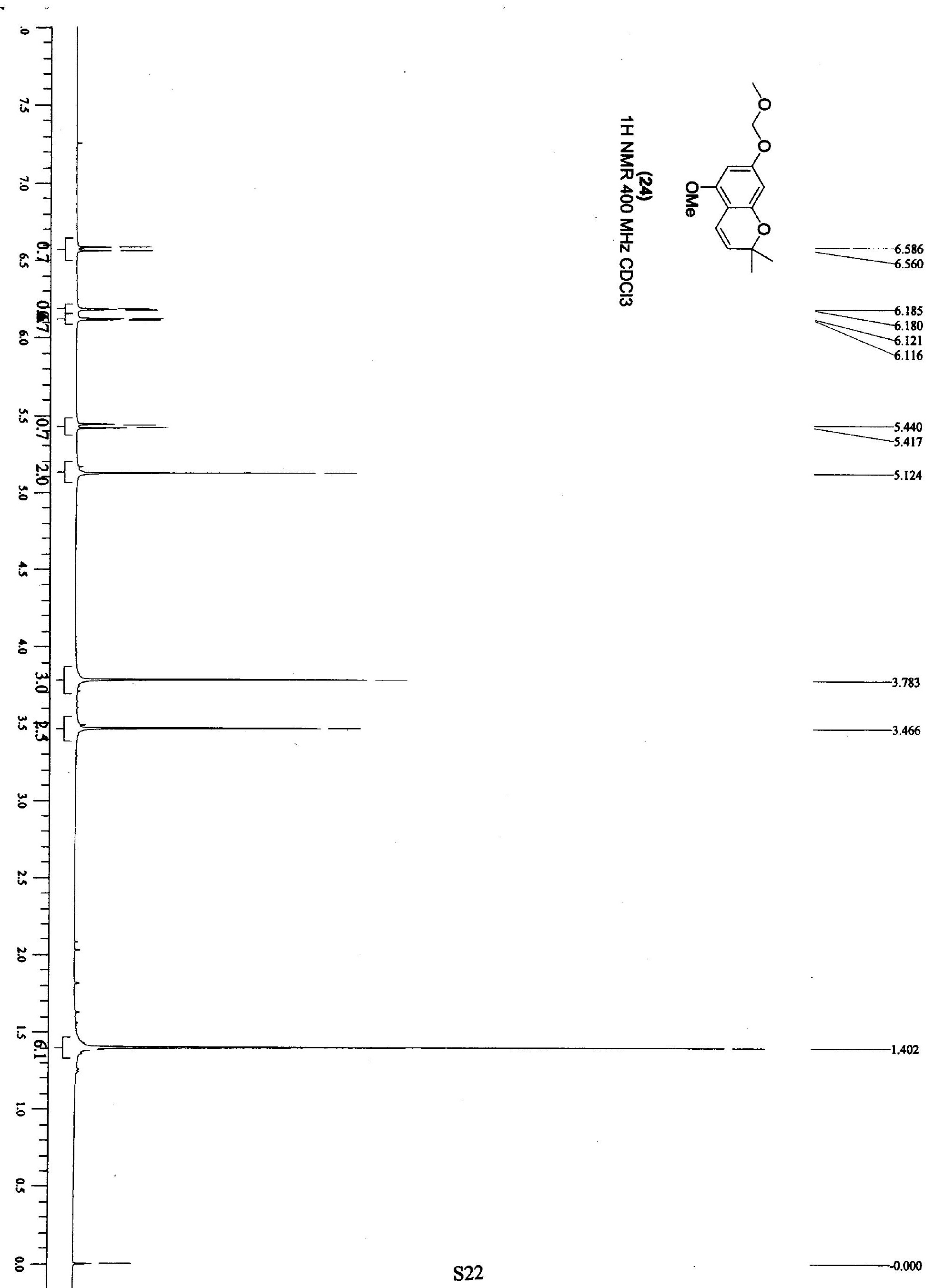




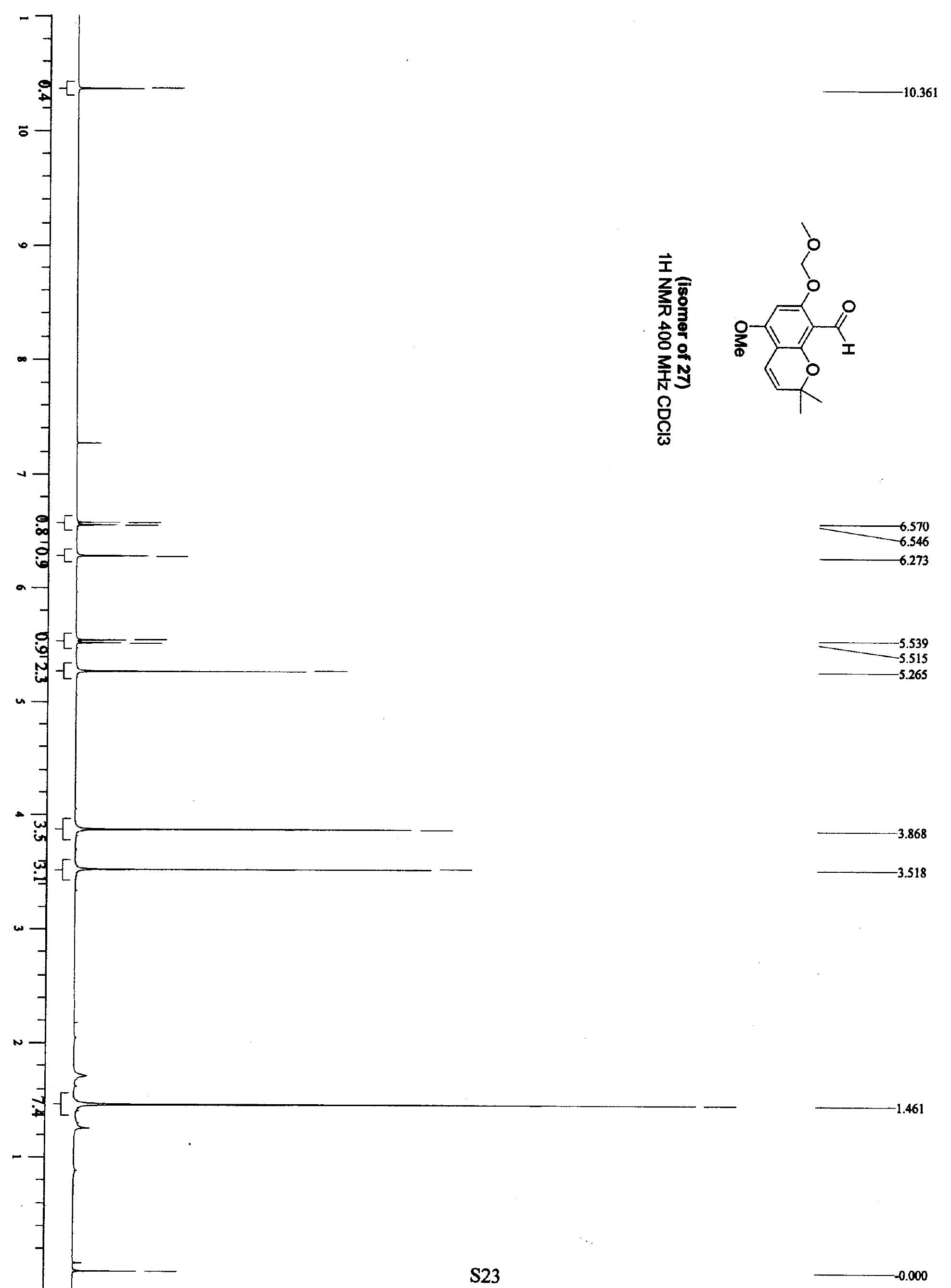




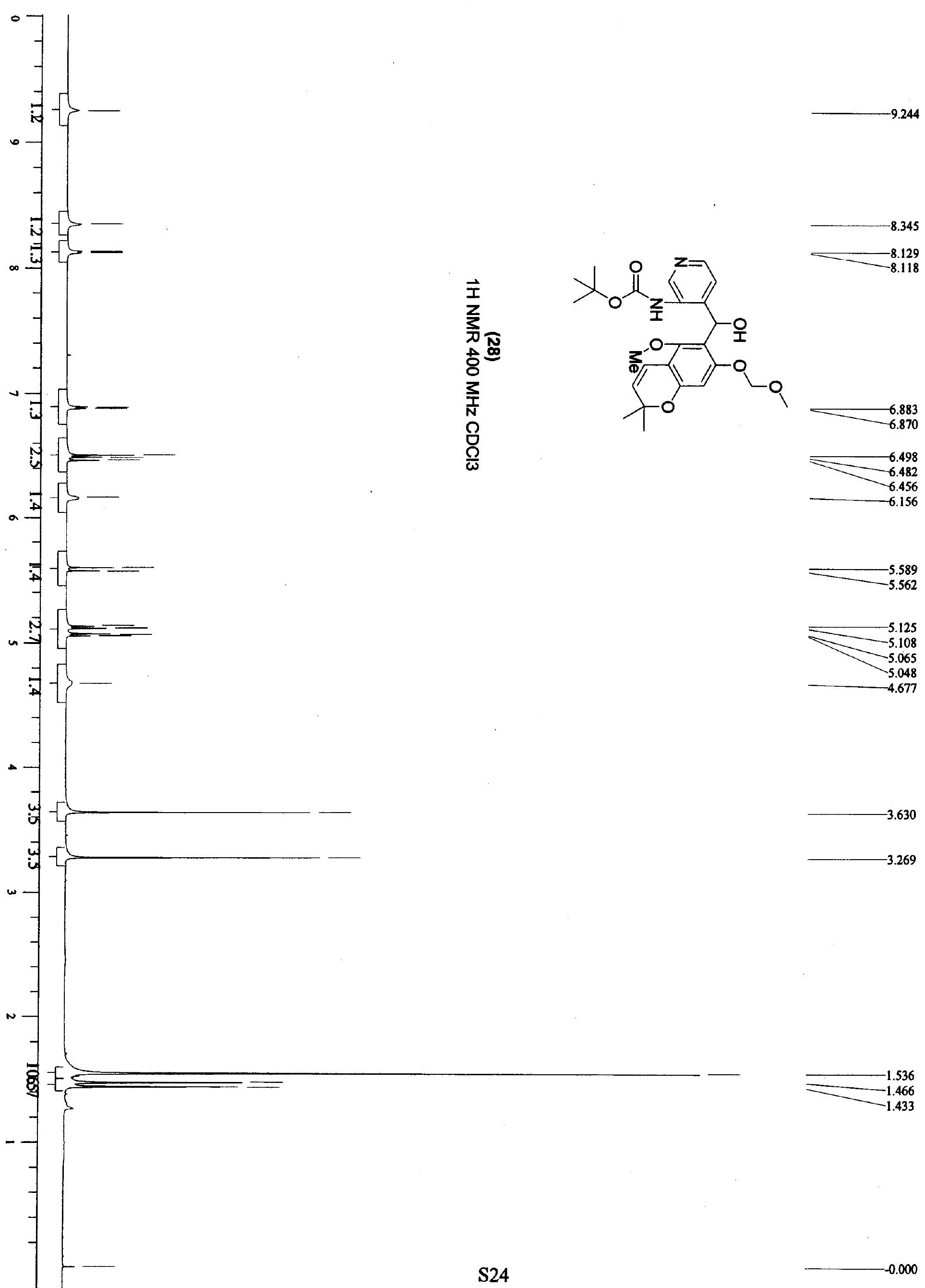




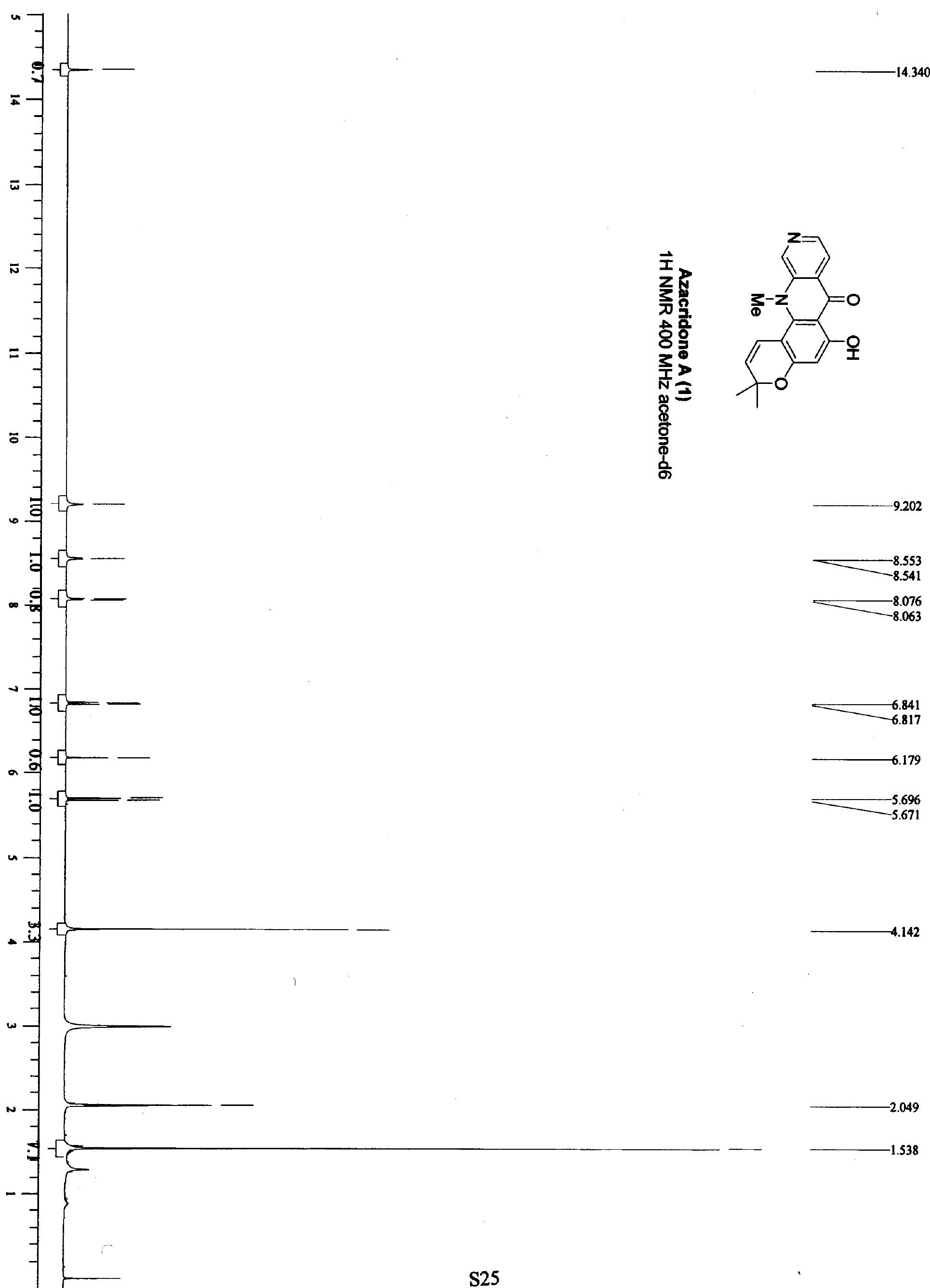




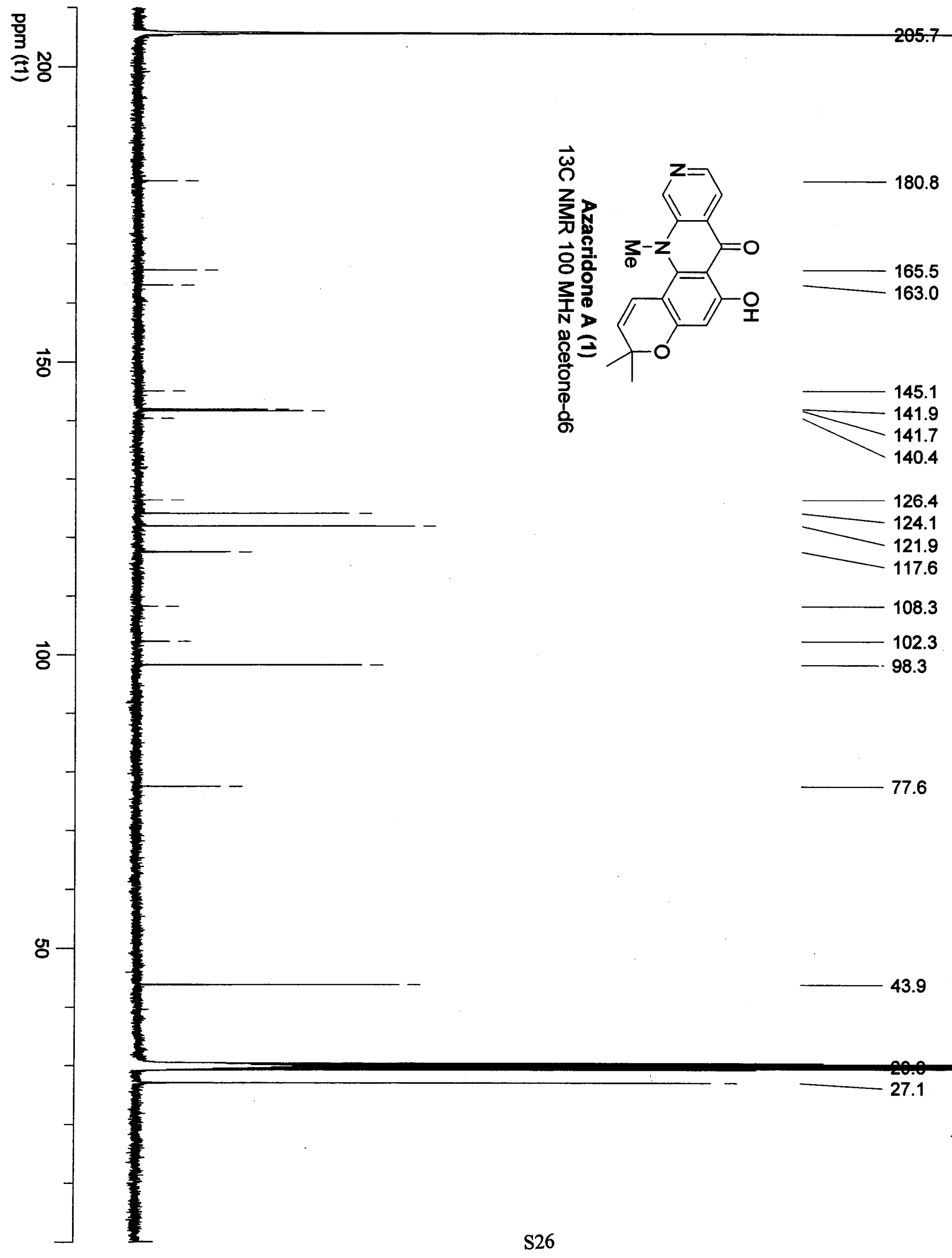

